\title{
Treatment of invasive fungal infections in cancer patients - updated recommendations of the Infectious Diseases Working Party (AGIHO) of the German Society of Hematology and Oncology (DGHO)
}

\author{
Sabine Mousset • Dieter Buchheidt • Werner Heinz • Markus Ruhnke • Oliver A. Cornely • \\ Gerlinde Egerer • William Krüger • Hartmut Link • Silke Neumann • Helmut Ostermann • \\ Jens Panse • Olaf Penack • Christina Rieger • Martin Schmidt-Hieber • Gerda Silling • \\ Thomas Südhoff • Andrew J. Ullmann • Hans-Heinrich Wolf • Georg Maschmeyer • \\ Angelika Böhme
}

Received: 14 May 2013 / Accepted: 29 July 2013 / Published online: 12 September 2013

(C) The Author(s) 2013. This article is published with open access at Springerlink.com

\begin{abstract}
The Infectious Diseases Working Party (AGIHO) of the German Society of Hematology and Oncology (DGHO) here presents its updated recommendations for the treatment of documented fungal infections. Invasive fungal infections are a main cause of morbidity and mortality in cancer patients undergoing intensive chemotherapy regimens. In recent years, new antifungal agents have been licensed, and agents already approved have been studied in new indications.
\end{abstract}

S. Mousset $(\square)$

Interdisziplinäres Zentrum für Palliativmedizin, Agaplesion Markus

Krankenhaus, Wilhelm Epstein-Straße 4, 60431 Frankfurt, Germany

e-mail: smousset@gmx.net

D. Buchheidt

III. Medizinische Klinik, Hämatologie und Internistische Onkologie, Universitätsmedizin Mannheim, Theodor-Kutzer-Ufer 1-3,

68167 Mannheim, Germany

W. Heinz

Schwerpunkt Infektiologie, Medizinische Klinik und Poliklinik II, Universitätsklinikum Würzburg, Josef-Schneider-Straße 2,

97080 Würzburg, Germany

M. Ruhnke

Abt. Onkologie und Hämatologie, Med. Klinik u. Poliklinik II, Campus Charité Mitte, Charité Universitätsmedizin, Charitéplatz 1, 10117 Berlin, Germany

O. A. Cornely

Department I of Internal Medicine, Clinical Trials Centre Cologne, ZKS Köln, BMBF 01KN1106, Cologne Excellence Cluster on Cellular Stress Responses in Aging-Associated Diseases (CECAD), University of Cologne, Cologne, Germany

\section{G. Egerer}

Med. Klinik V, Universität Heidelberg, Im Neuenheimer Feld 410, 69120 Heidelberg, Germany
The choice of the most appropriate antifungal treatment depends on the fungal species suspected or identified, the patient's risk factors (e.g., length and depth of neutropenia), and the expected side effects. This guideline reviews the clinical studies that served as a basis for the following recommendations. All recommendations including the levels of evidence are summarized in tables to give the reader rapid access to the information.

W. Krüger

Medizinische Klinik C, Ferdinand-Sauerbruch-Strasse,

Ernst-Moritz-Arndt-Universität, 17487 Greifswald, Germany

H. Link

Klinik für Innere Medizin I, Westpfalz-Klinikum Kaiserslautern, Hellmut-Hartert-Str. 1, 67655 Kaiserslautern, Germany

\section{S. Neumann}

Department of Hematology and Oncology, Georg-August-University Göttingen, Göttingen, Germany

\section{H. Ostermann}

Department Hematology and Oncology, University of Munich, Marchionistrasse 15, 81377 Munich, Germany

\section{J. Panse}

Klinik für Onkologie, Hämatologie und Stammzelltransplantation, Universitätsklinikum Aachen, Pauwelsstr. 30

52074 Aachen, Germany

O. Penack

Medizinische Klinik mit Schwerpunkt Hämatologie, Onkologie und Tumorimmunologie, Campus Virchow Klinikum, Charité Universitätsmedizin Berlin, Augustenburger Platz 1

13353 Berlin, Germany 
Keywords Mycoses $\cdot$ Antifungal agents $\cdot$ Aspergillosis · Invasive candidiasis $\cdot$ Hematologic malignancies

\section{Introduction}

In cancer patients, invasive fungal disease (IFD) remains an important complication causing considerable mortality and morbidity. Chemotherapy or transplantation procedures are often delayed or postponed in patients with IFD which might lead to impaired overall survival. In recent years, new antifungal agents have been licensed or agents already approved have been studied in new indications, which is why the Infectious Diseases Working Party (AGIHO) of the German Society of Hematology and Oncology (DGHO) here presents its updated recommendations.

The current version of the guideline focuses on patients with solid tumors or hematologic malignancies and includes treatment of acute invasive infections caused by the species Aspergillus, Candida, Cryptococcus, Scedosporium, Fusarium, Zygomycetes, and Trichosporon. Chronic or superficial fungal infections were excluded. We hereby give an overview of the treatment options for invasive fungal disease and classify the recommendations according to their evidence level.

\section{Rieger}

Department of Hematology/Oncology, University of Munich,

Campus Großhadern, Munich, Germany

M. Schmidt-Hieber

HELIOS Clinic Berlin Buch, Clinic for Hematology, Oncology and

Tumorimmunology, Schwanebecker Chaussee 50

13175 Berlin, Germany

G. Silling

Department of Internal Medicine A, Hematology/Oncology,

University of Muenster, Muenster, Germany

T. Südhoff

II. Medizinische Klinik, Klinikum Passau, Innstraße 76, 94032 Passau, Germany

\section{A. J. Ullmann}

Schwerpunkt Infektiologie, Medizinische Klinik und Poliklinik II, Universitätsklinikum Würzburg, Josef-Schneider-Straße 2,

97080 Würzburg, Germany

H.-H. Wolf

Department of Oncology, University Hospital Halle, Ernst-Grube-Str. 40, 06120 Halle, Germany

G. Maschmeyer

Hematology, Oncology and Palliative Care, Klinikum Ernst von Bergmann, Charlottenstrasse 72, 14467 Potsdam, Germany

\section{A. Böhme}

ONKOLOGIKUM, Frankfurt am Museumsufer, Schaubstraße 16, 60596 Frankfurt, Germany

\section{Methods}

Data Clinical studies and guidelines published in English were searched via Medline from 1990 up to June 2012. Studies published in form of abstracts were only considered if their data lead to a change in the level of recommendation for a given treatment.

Evidence criteria Wherever possible, evidence categories of the "Infectious Diseases Society of America" (IDSA) were integrated (Table 1) [80]. Evidence levels for treatment in neutropenic patients were "downgraded" (e.g., from AII to BII) if available studies only included a small proportion of neutropenic patients or no neutropenic patients at all.

Assessment of license The status of license for the presented medications was not considered, and substances are solely recommended based on available clinical study data. Therefore, the responsibility for a selected therapy is exclusively that of the ordering physician. Currently used dosages of available fungal agents are listed in Table 6.

Finding consensus These recommendations were first prepared by a panel of experts in the field of infections in immunocompromised patients during two meetings and then circulated via e-mail. All recommendations and evidence levels were then voted first via e-mail and then during a meeting of the AGIHO consensus group general assembly.

\section{Treatment of invasive Aspergillus infections}

Acute invasive pulmonary aspergillosis (IPA) is the most frequent manifestation of systemic aspergillosis in

Table 1 Categories indicating the strength of each recommendation for or against its use, and grades indicating the quality of evidence on which recommendations are based. Criteria of the IDSA [80]

A Good evidence to support a recommendation for use

B Moderate evidence to support a recommendation for use

C Poor evidence to support a recommendation for use

D Moderate evidence to support a recommendation against use

E Good evidence to support a recommendation against use

I Evidence from at least 1 properly randomized, controlled trial

II Evidence from at least 1 well-designed clinical trial without randomization, from cohort or case-controlled analytic studies (preferably from more than one center); from multiple time series; or from dramatic results of uncontrolled experiments

III Evidence from opinions of respected authorities, based on clinical experience, descriptive studies, or reports of expert committees 
neutropenic patients [162] with a fatality rate that ranges from 30 to $60 \%[11,116,123]$. Early treatment at first signs of infection is mandatory and improves the chance of survival (BIII) [25].

Neutropenic patients Although data are limited, the response to liposomal amphotericin B is reduced by $>20 \%$ in the neutropenic host (43\%) as compared to non-neutropenic patients (67\%) with invasive aspergillosis as compared to voriconazole where response rates were similar in patients with and without neutropenia (50.8 vs. $54.3 \%$, respectively) $[35,65]$.

Antifungal therapy

Azoles

Voriconazole In an open, non-comparative study, voriconazole showed a response rate of $59 \%$ in the primary treatment of invasive aspergillosis and a $38 \%$ response rate when used for salvage treatment [41]. The randomized comparison between voriconazole and amphotericin B deoxycholate (D-AmB) (both followed by other licensed antifungal agents in the case of failure/intolerance) included patients with a malignant underlying disease or another immunocompromising condition. In this study, voriconazole had a significantly higher response and survival rate including less Aspergillus-related deaths and side effects than D-AmB. Since then, voriconazole has been established as the gold standard for treatment of invasive aspergillosis $[65,186]$. Although the study design has some limitations (e.g., lack of details of administered antifungal agents in the comparator arm and inclusion of cases without sufficient evidence for IFD), we recommend voriconazole as the standard therapy for aspergillosis (AI). In case of a different first-line therapy, voriconazole is recommended for salvage treatment of invasive aspergillosis (BII). In an observational efficacy and safety analysis, clinical response with voriconazole as monotherapy was observed in 42/72 patients [76]. In addition, voriconazole is more active in vitro against Aspergillus terreus compared to D-AmB $[59,91]$.

After oral or intravenous administration, adequate concentrations of voriconazole were documented in many body sites including brain parenchyma [56]. However, a large variability in trough plasma levels has been observed [130]. A recent study demonstrated a positive correlation between plasma levels, clinical efficacy, and toxicity. Plasma concentrations of $>1 \mathrm{mg} / \mathrm{L}$ were found to be correlated with response to therapy. However, plasma levels $>5.5 \mathrm{mg} / \mathrm{L}$ were associated with neurotoxicity [131]. Therapeutic concentrations could only be achieved with a dose of $2 \times 200 \mathrm{mg}$ oral voriconazole in about $50 \%$ of patients, increasing to about $70 \%$ with $2 \times$ $300 \mathrm{mg}$ and nearly $100 \%$ with $2 \times 400 \mathrm{mg}$ given [131] (see also "Therapeutic drug monitoring of antifungal agents" section).
Main side effects of voriconazole therapy are reversible visual disturbances in up to $40 \%$ of patients. Primarily due to cytochrome P450 metabolism, voriconazole can interact with a large number of other drugs. Therefore, contraindications and comedications (e.g., vinca alkaloids, statins, chinidin) have to be monitored closely.

Posaconazole Posaconazole was licensed for second-line therapy of aspergillosis in 2005 by EMA. In a retrospective comparison of posaconazole versus standard treatment (e.g., AmB lipid formulations and itraconazole) in a historical control group, patients (including neutropenic patients) demonstrated a response rate of 42 versus $26 \%$, respectively [189]. The response to posaconazole correlated with plasma concentrations [189]. Additionally, in a retrospective not stratified investigation, the response rate of posaconazole compared favorably to high-dose AmB lipid formulations ( $\geq 7.5 \mathrm{mg} / \mathrm{kg}$ ) or caspofungin plus highdose lipid-AmB in salvage therapy for invasive aspergillosis. Response rates were 40 versus 8 versus $11 \%$, respectively, in 143 patients with hematological malignancies [140]. Thus, posaconazole is recommended as a salvage therapy in this patient group (BII). Posaconazole is generally well tolerated, also in long-term use [138]. The drug is a substrate of both uridine diphosphate glucuronosyltransferase and the transporter Pglycoprotein, but is not significantly metabolized by cytochrome $\mathrm{P} 450$, although the compound inhibits isoenzyme 3A4 [50, 192]. Therefore, different potential interactions have to be considered if co-medications are given. Posaconazole also demonstrates activity in mucormycosis, which is clinically difficult to distinguish from aspergillosis of the lungs, paranasal sinuses, or CNS [181]. Up to now, posaconazole is only available as an oral suspension and should be administered with food. The co-medication with a proton pump inhibitor might limit the posaconazole exposure.

\section{Echinocandins}

Caspofungin A phase II study of caspofungin as first-line therapy demonstrated survival rates of $66 \%$ (6 weeks) and $53 \%$ (12 weeks) in 61 patients with hematologic malignancies [184]. Most patients were not in remission of their underlying disease, $72 \%$ presented with severe neutropenia for $>10$ days, and in contrast to other studies, aspergillosis had to be proven or probable strictly according to European Organization for Research and Treatment of Cancer (EORTC)MSG criteria [10]. An EORTC study in allogeneic stem celltransplanted patients was stopped due to inadequate recruitment with 42 patients enrolled. At week 6 and week 12, the survival rate was 79 and $50 \%$, respectively [68]. In a prospective observational registry, 12 out of 20 patients responded to caspofungin first-line treatment [98]. In summary, the AGIHO working group considers caspofungin as a therapeutic option in the first-line therapy (CII) (vote, 7:4, 3 abstentions). 
When used for salvage treatment, caspofungin resulted in a response rate of $45-49 \%$ in two non-comparative studies of patients with invasive aspergillosis and failure of or intolerability to standard antifungal therapy $[100,112]$. A case collection of 118 patients demonstrated a response rate of $61 \%$ [52]. In the CAN-DO study, 45/81 patients responded to caspofungin treatment [98]. As caspofungin is well tolerated, it is recommended for salvage therapy (BII).

Micafungin Micafungin has been investigated mostly in salvage therapy studies and retrospective analyses as mono- and particularly combination therapy which resulted in efficacy rates of about $25-36 \%[40,82]$. Therefore, the role of micafungin in the treatment of acute invasive aspergillosis has not been clarified so far (CII).

Anidulafungin Data on anidulafungin as a monotherapy for the treatment of invasive aspergillosis are too limited to allow inclusion of this drug into therapy algorithms of invasive aspergillosis (see "Combination therapy" section).

\section{Amphotericin B formulations}

Amphotericin B lipid complex $(A B L C)$ A retrospective analysis of a large company-based dataset (Collaborative Exchange of Antifungal Research) showed a $44 \%$ efficacy in about 400 patients with IA (55\% response in 42 neutropenic patients) [31] and $31 \%$ response rate in patients after allogeneic stem cell transplantation [74], mainly in patients with second-line therapy (BII). There are no sufficient data for first-line therapy (CIII).

Liposomal amphotericin $B(L-A m B)$ Several non-comparative studies with L-AmB for second-line therapy exist which included only smaller numbers of patients and resulted in response rates of 50-70\% [108, 147]. In a pooled efficacy analysis, this resulted in a response rate of $47 \%$ for the treatment of invasive aspergillosis [32]. In a randomized stud$\mathrm{y}, \mathrm{L}-\mathrm{AmB}$ was equally efficacious compared to $\mathrm{D}-\mathrm{AmB}$ in the first-line therapy of invasive mycosis [92], but the study was not restricted to patients with IA. The efficacy of L-AmB versus ABLC in the first-line therapy has been compared in an analysis of eight open-label studies with more than 1,000 patients resulting in a response rate of 61 versus $46 \%$ favoring L-AmB over ABLC [121]. A retrospective study in 158 consecutive patients with mainly acute leukemia or allogeneic stem cell transplantation receiving L-AmB or ABLC for invasive aspergillosis resulted in a poor outcome of both groups (12\%) [58]. ABLC was associated with significantly higher nephrotoxicity compared to L-AmB [58].

The studied dosages of $\mathrm{L}-\mathrm{AmB}$ for treatment of invasive aspergillosis are $1-10 \mathrm{mg} / \mathrm{kg} /$ day (manufacturer recommendation, 1-3 mg/kg) [35, 43, 92]. A randomized study comparing LAmB 4 versus $1 \mathrm{mg} / \mathrm{kg}$ resulted in similar efficacy rates, but survival at day 14 and response in patients with proven aspergillosis were higher in the 4-mg/kg arm [43]. A randomized comparison of L-AmB 3 versus $10 \mathrm{mg} / \mathrm{kg}$ (mainly cancer patients) in first-line therapy of invasive aspergillosis showed equal efficacy but an increased toxicity with the higher dosage [35]. The response rate was high and comparable to voriconazole.

In summary, we recommend L-AmB (3 $\mathrm{mg} / \mathrm{kg})$ for the first-line treatment with lesser strength than voriconazole (AII), since all available trials did not compare L-AmB with a standard treatment. L-AmB may be also used as second-line treatment (BII) [180].

Amphotericin B deoxycholate (D-AmB) Until 2002, intravenous therapy with $\mathrm{D}$-AmB had been the therapeutic gold standard for IA with response rates of 30-50\%. Maximum tolerable daily dosages of up to $1.5 \mathrm{mg} / \mathrm{kg}$ have been recommended. Comparative clinical studies on dose regimens are, however, not available. Due to its high toxicity and inferiority compared to voriconazole in a randomized controlled study [65], we strongly recommend not to use D-AmB (EI).

\section{Combination therapy}

The benefit of combination of D-AmB plus 5-flucytosine has not been substantiated by appropriate clinical trials. There are limited data from uncontrolled trials with response rates of $42 \%$ for combinations of L-AmB and caspofungin as primary or salvage therapy [81], $55 \%$ for combinations of caspofungin and polyenes or triazoles in cancer patients [99], and a significantly reduced mortality rate for patients receiving caspofungin plus voriconazole versus voriconazole alone in refractory aspergillosis in a historically controlled trial among stem cell transplant recipients [102]. A randomized pilot study comparing the combination of L-AmB plus caspofungin (standard dosages) to high-dose L-AmB in patients with hematological malignancies resulted in a better response with the combination at the end of treatment, but similar overall survival after 12 weeks and the number of patients included $(n=30)$ was rather small [27]. A recent large prospective randomized trial comparing voriconazole monotherapy to voriconazole plus anidulafungin for first-line therapy did not show any superiority of the combination for the primary endpoint of overall survival at week 6 . In a post hoc analysis for patients with galactomannan-positive aspergillosis, survival at week 6 was significantly better in the group with the combination treatment. These data have not been published in a peer-reviewed journal, and therefore, up to now final assessment cannot be made (Marr abstract ECCMID 2012, LB 2812) (CIII). In summary, data of combination treatment regimens are very limited, so that combinations cannot generally be recommended and may be considered for refractory disease and/or severely ill patients (CIII). 


\section{Salvage therapy}

It is important to differentiate between a replacement of firstline therapy with another substance because of toxicity from change of substance due to refractory infection. Generally, given a stable clinical situation, a minimum of 14 days of full-dose treatment is recommended before a reliable first clinical response assessment can be done.

Apart from evident failure due to intrinsic resistance of the pathogen (e.g., A terreus to AmB), lack of adequate drug levels (see "Therapeutic drug monitoring of antifungal agents"), intolerance, or severe organ toxicity, non-response of IA to an established antifungal therapy should be stated with caution $[104,163]$. A temporary increase in the volume of pulmonary lesions during the first week of treatment or neutrophil recovery must not be misinterpreted as antifungal treatment failure [26]. Since most available studies for salvage therapy included patients who failed to respond to $\mathrm{D}-\mathrm{AmB}$ as a first-line treatment, no general conclusion can be drawn to salvage treatment after failure of newer antifungal agents (e.g., triazoles and echinocandins) (CIII).

Invasive aspergillosis occurring during posaconazole or voriconazole prophylaxis Recommendations for the treatment of invasive mycoses have to consider the prophylactic regimens, but so far, studies in this field are lacking. Therefore, the expert group recommends the switch to another class of antifungal agent, but to take into account an inadequate exposition to the prophylactic agent (CIII).

\section{Duration of antifungal treatment}

Generally, the antifungal therapy should be continued during the period of neutropenia and until the manifestations of IA have been completely resolved or are reduced to residual scarring, up to 12 weeks [65] (BIII).

\section{Other manifestations}

Invasive sinus aspergillosis Severe Aspergillus sinusitis most often occurs in allogeneic stem cell transplant recipients (2$3 \%$ ) and is primarily caused by Aspergillus fumigatus or Aspergillus flavus [42, 182]. Frequently, additional surgical debridement is required (BII) (see "Interventional strategies"). Overall, Aspergillus sinusitis has been associated with a mortality rate of $26.1 \%$ while treated with $\mathrm{AmB}$ formulations [95]. Therapy recommendations do not differ from pulmonary manifestations (see Table 2).

Aspergillosis of the CNS Aspergillus spp. rarely cause meningitis or micro-abscesses of the brain, but macro-abscessesespecially in severe immunosuppressed patients - are most often caused by $A$. fumigatus or A. flavus. Patients with
Table 2 Treatment of invasive Aspergillus infections in hemato-oncological patients

First-line treatment of invasive

pulmonary aspergillosis

\begin{tabular}{ll} 
Voriconazole & AI \\
Liposomal AmB & AII \\
Caspofungin & CII \\
Micafungin & CII \\
ABLC & CIII \\
Anidulafungin + voriconazole & CIII \\
D-AmB & EI \\
econd-line treatment of invasive & \\
pulmonary aspergillosis & \\
Voriconazole & BII \\
Caspofungin & BII \\
Posaconazole & BII \\
Liposomal AmB & BII \\
ABLC & BII \\
Micafungin & CIII \\
Voriconazole + caspofungin & CIII \\
CNS infection & \\
Voriconazole & AII \\
Liposomal AmB $(\geq 5$ mg/kg) & BIII \\
Surgical intervention & AII \\
inusitis & \\
Antifungals: see invasive & \\
pulmonary aspergillosis & \\
Surgical intervention & BII \\
\hline
\end{tabular}

aspergillosis within the CNS typically present with focal neurological signs such as pareses or seizures. Comparable studies regarding drug treatment of CNS aspergillosis do not exist, but it is clear that the prior standard therapy with DAmB is not effective [161]. Due to its good permeability into the cerebrospinal fluid, voriconazole is recommended for primary treatment [152] and has shown a survival rate of $30-40 \%[41,159,160]$ (AII). Successful therapy with L$\mathrm{AmB}$ has also been reported in case reports $[77,161]$ and might be administered in case of contraindication, intolerance, or poor response to voriconazole (BIII). A retrospective study of 81 patients with CNS aspergillosis resulted in significantly better survival in patients undergoing surgery [160]. Therefore, surgical resection of singular lesions is recommended together with systemic antifungal treatment (AII).

\section{Treatment of invasive Candida infections}

The most common causes of IFD in cancer patients are yeast pathogens, in particular Candida albicans, followed by nonCandida albicans species (e.g., Candida glabrata, Candida krusei, Candida parapsilosis, Candida tropicalis) [122, 151, 183]. In patients with hematological malignancies primarily 
non-Candida albicans species (e.g., C. tropicalis, C. glabrata) have been identified in most studies [83, 174, 183]. The proper identification of the infecting Candida spp. is crucial for the choice of antifungal therapy (e.g., fluconazole-resistant Candida spp.) [178]. Due to frequent colonization with Candida species in hospitalized patients, detection of yeasts in non-sterile material is not sufficient to confirm invasive Candida infection. Colonization index and Candida scores have been developed to predict invasive Candida infections for non-neutropenic patients in the ICU [94], but are not validated for patients with hematological malignancies. In patients with acute leukemia, the degree of mucosal damage and profound neutropenia are the most important risk factors for invasive Candida infection in contrast to other patient groups at risk for IFD with other "classical" risk factors (e.g., central venous catheters) [23, 141]. The high pathogen-related mortality, which may approach $50 \%$, should prompt immediate initiation of therapy in all patients with suspected yeasts in the blood culture, as delays in treatment result in an increased mortality $[48,111]$.

Neutropenic patients Although data are limited, the response rate as shown for therapy with echinocandins or amphotericin $\mathrm{B}$ formulations is reduced by approximately $15-20 \%$ in neutropenic host as compared to other (non-neutropenic) patients with candidemia $[86,110,128]$. According to data from a large cohort study in patients treated with ABLC, a favorable clinical response was observed in $61 \%$ of all patients infected with Candida species, but was as low as $20 \%$ in patients who were neutropenic at the time of diagnosis or became neutropenic during antifungal treatment [75].

Antifungal therapy

Azoles

A randomized clinical trial [5] and a cohort study [7] did not show a significant difference in antifungal efficacy between fluconazole (400 mg daily) and D-AmB (25-50 mg daily; $0.67 \mathrm{mg} / \mathrm{kg}$ daily) in neutropenic patients with systemic Candida infection. There was a trend to a lower response to antifungal treatment in patients with neutrophil counts $\geq 1,000 / \mu \mathrm{l}$ at enrolment treated with fluconazole $(58 \%)$ as compared to D-AmB (74 \%). However, in the small subset of patients with neutrophil counts $<1,000 / \mu 1$, fluconazole appeared to be superior to D-AmB (response rate $77 \%$ for fluconazole vs. $48 \%$ for $\mathrm{D}-\mathrm{AmB}$ ).

Due to the better in vitro susceptibility of voriconazole in non-Candida albicans species, this agent may provide an alternative to fluconazole, but only data from salvage therapy studies are available [135]. Neutropenic patients were not included in a randomized trial comparing voriconazole to the regimen of $\mathrm{D}-\mathrm{AmB}$ followed by fluconazole in the primary treatment of candidemia [85].
Data on the effect of itraconazole and posaconazole in candidemia are lacking.

\section{Amphotericin B formulations}

The major disadvantages of D-AmB are nephrotoxicity, hypokalemia, and acute infusion-related side effects. Increasing number of publications report long-term nephrotoxicity with $\mathrm{D}-\mathrm{AmB}$ resulting in inferior survival especially in stem cell transplant patients [16, 61, 107, 180, 196].

A recent study comparing $\mathrm{L}-\mathrm{AmB}$ with micafungin for first-line treatment of invasive Candida infections demonstrated a high efficacy of L-AmB [86]. Overall success at the end of therapy was $89.6 \%$ for micafungin and $89.5 \%$ for L$\mathrm{AmB}$, respectively. Efficacy was independent of the Candida spp. and primary site of infection, as well as neutropenia status, Acute Physiology and Chronic Health Evaluation (APACHE) II score, and central venous catheter removal.

An analysis of eight open-label studies on D-AmB and AmB lipid formulations showed an efficacy rate of $75 \%$ in ABLC-treated and $80 \%$ in L-AmB treated patients with invasive Candida infections [121]. Amphotericin B colloidal dispersion $(\mathrm{ABCD})$ is unavailable in Germany, and tolerability is less favorable when compared to ABLC or L-AmB.

\section{Echinocandins}

The results of a study comparing fluconazole ( $800 \mathrm{mg}$ on day 1 and then $400 \mathrm{mg}$ daily) versus anidulafungin (200 mg on day 1 and then $100 \mathrm{mg}$ daily) demonstrated superiority of anidulafungin (response rate 75 vs. $60 \%$ ) in the treatment of candidemia and invasive Candida infections in a general population with only few neutropenic patients (3\%) [143]. Anidulafungin fulfilled the criteria for non-inferiority in nonneutropenic patients (AI). A subgroup analysis demonstrated the superiority of anidulafungin compared to fluconazole in patients diagnosed with C. albicans infections (95 vs. $81 \%$ ).

In general, echinocandins (anidulafungin, caspofungin, and micafungin) have been tested for the treatment of candidemia in various controlled clinical trials [86, 110, 143], but the number of neutropenic patients in these trials was limited (max. $10 \%$ ).

A direct comparison of caspofungin and micafungin showed similar efficacy and safety. In addition, no difference in safety or efficacy was seen in patients treated with two different dosages of micafungin (100 or $150 \mathrm{mg} /$ day) [128]. Further studies comparing one echinocandin to another echinocandin are lacking.

Higher dosages of caspofungin ( $150 \mathrm{vs.} 70 / 50 \mathrm{mg} /$ day) and micafungin ( 150 vs. $100 \mathrm{mg} /$ day) showed a trend towards improved efficacy in subgroups of patients (APACHE II score $>20$, neutropenia) and might be used in selected patients [19, 36, 128].

A reduced sensitivity to fluconazole ("susceptible dose dependent") is frequently seen in Candida species such as $C$. glabrata and C. tropicalis. Non-Candida albicans infections 
are more common in patients with hematologic malignancies than in those with solid tumors, which favors initial broadspectrum antifungal therapy with an echinocandin (e.g., anidulafungin, caspofungin, or micafungin) in this patient group (BI) [66].

A switch to (oral) fluconazole $(800 \mathrm{mg} /$ day as loading dose, followed by $400 \mathrm{mg} /$ day $)$ or voriconazole $(6 \mathrm{mg} / \mathrm{kg}$ bid as loading dose, followed by $4 \mathrm{mg} / \mathrm{kg}$ bid) is optional. If a susceptible species has been confirmed, the patient is clinically stable and has no prior azole exposure (BII) [127].

In summary, due to its good efficacy especially against non-Candida albicans spp. as well as its good safety profile and the importance of a fungicidal mode of action, echinocandins or L-AmB may be regarded as the drug of choice in severely ill, clinically instable patients with organ dysfunction, especially in patients with neutropenia (BI). For non-neutropenic patients, data on echinocandins, liposomal $\mathrm{AmB}$, and voriconazole allow a recommendation level of AI (see Table 3). In non-neutropenic patients with no prior azole exposure, fluconazole is an alternative for the treatment of yeasts in the blood culture while awaiting susceptibility tests (AI; vote, 8:4; abstentions, 2) (see Table 3).

\section{Combination therapy}

In non-neutropenic patients, the combination of fluconazole (800 mg per day) plus placebo with fluconazole plus D-AmB $(0.7 \mathrm{mg} / \mathrm{kg}$ per day, with the placebo/D-AmB component given only for the first 5-6 days) did not show antagonism, a similar mortality but improved clinical outcome (69 \% for Flu/

Table 3 Treatment of invasive Candida infections in hemato-oncological patients

\begin{tabular}{ll} 
Candidemia & \\
Neutropenic patients & \\
Echinocandins & $\mathrm{BI}$ \\
Liposomal AmB & $\mathrm{BI}$ \\
Non-neutropenic patients & \\
Echinocandins & $\mathrm{AI}$ \\
Liposomal AmB & $\mathrm{AI}$ \\
Voriconazole & $\mathrm{AI}$ \\
Fluconazole & $\mathrm{AI}$ \\
Hepatosplenic candidosis & \\
Neutropenic patients & \\
Liposomal AmB/ABLC & $\mathrm{BIII}$ \\
Echinocandins & $\mathrm{BIII}$ \\
Voriconazole & $\mathrm{CIII}$ \\
Non-neutropenic patients & \\
Fluconazole & $\mathrm{BIII}$ \\
Steroids & $\mathrm{CIII}$ \\
\hline
\end{tabular}

${ }^{\mathrm{a}}$ If no prior azole exposure
D-AmB vs. $56 \%$ for Flu/Placebo) and more rapid eradication of yeasts from bloodstream compared to fluconazole alone [146]. However, in patients with cancer or hematological malignancies, there are no data about combination therapies for invasive Candida infections.

\section{Salvage therapy}

Data on second-line therapy in cancer patients, in particular during neutropenia, are limited to case reports and specific recommendations cannot be given.

\section{Duration of antifungal therapy}

Duration of treatment in non-neutropenic patients is recommended for at least 14 days after the first negative blood culture and resolution of signs and symptoms of candidemia (BIII) [127, $153,178]$, but should be adapted in case of organ manifestations.

Acute disseminated candidosis

Acute disseminated candidosis is the most severe form of systemic Candida infection in neutropenic patients. It is characterized by hemodynamic instability, persistent positive blood cultures, and deep organ and/or skin involvement. Patients present with sepsis, spiking fever, shaking chills, and disseminated lesions of the skin and sometimes other organ infections such as endophthalmitis or osteomyelitis [18, 109]. Echinocandins and L-AmB are recommended as initial antifungal treatment (BIII).

In addition to fundoscopy, an abdominal ultrasound (liver, spleen, kidneys) should be performed in neutropenic patients with candidemia after bone marrow recovery to exclude chronic disseminated infection/hepatosplenic candidosis that may not be associated with clinical symptoms other than fever (BIII).

Management of intravenous lines

Intravenous lines should be removed at initiation of antifungal therapy whenever feasible (AII). If the central venous lines are retained, the duration of candidemia increases (from 3 to 6 days) as does the mortality of patients [22, 87, 145, 193]. The role of central venous catheter removal in neutropenic patients is controversial as the gastrointestinal mucosa, damaged by cytotoxic chemotherapy, is thought to be the main port of entry for yeasts [6, 142, 198]. However, as the central venous line might be colonized, it is recommended that it should be removed also in neutropenic patients (AII). If the catheter has to be kept in place, patients should be treated with an echinocandin or LAmB (CII) as these agents have a better minimal inhibitory concentration in biofilms [84]. 
Chronic disseminated candidosis (CDC)

If fever persists after neutrophil recovery, hepatosplenic candidosis should be considered in hematological patients. $\mathrm{CDC}$ is usually not an acute life-threatening condition but may require systemic antifungal therapy for months. After stabilization of signs and symptoms, CDC is not a contraindication for the continuation of chemotherapy or hematopoietic stem cell transplantation $[78,125]$.

Data on antifungal treatment in patients with CDC are limited to case series with D-AmB given as a single therapy or in combination with flucytosine [172, 191], lipid formulations of amphotericin B [190], fluconazole [3, 79], or caspofungin [34]. Due to the need for prolonged antifungal therapy, oral agents such as fluconazole (400-800 mg/day) are recommended if the Candida strain was isolated and proven to be susceptible (BIII). Echinocandins or L-AmB should be used as initial therapy in unstable or refractory patients (BIII). Voriconazole is an alternative option (CIII). The duration of antifungal therapy in patients with CDC should be individualized and may be continued until the resolution of all radiographic signs or calcification of the lesions. In contrast, newer data suggest that hepatosplenic candidosis may represent an immune reconstitution syndrome as steroids (in addition to antifungal treatment) can lead to a rapid resolution of clinical signs [93] (CIII). In stable patients, intravenous therapy may be switched to oral medication (step down strategy). This strategy has not been studied in CDC so far, but is regarded as safe and effective in patients with candidemia (see above).

\section{Other manifestations}

CNS CNS infections caused by Candida spp. might be treated with L-Amb (BIII) or voriconazole (BIII) [70, 115, 157]. Animal studies show a better penetration of L-AmB into the brain tissue as compared to ABLC [57]. Fluconazole might be a treatment option for CNS Candida infection if the patient is clinically stable, without prior azole exposure, not neutropenic, and if sensitivity to this agent has been documented by in vitro resistance testing (CIII). Preclinical data further suggest that echinocandins (e.g., caspofungin) may be useful to treat Candida infections of the CNS albeit the poor CNS penetration of these agents have to be taken in account - at least if the blood-brain barrier is intact [45].

Treatment should be continued for an additional 4 weeks following the resolution of manifestations (BIII) [124, 127]. In case of a brain abscess, additional drainage or surgical resection is recommended.

Urinary tract For urinary tract Candida infection, fluconazole has been proven in mainly non-neutropenic patients and is the drug of choice, if a susceptible Candida spp. is cultured (AI). If a urine catheter is in place, it should be removed (BII) $[127,153]$.

\section{Treatment of mucormycosis}

Mucormycosis is an emerging invasive fungal infection in patients with hematological malignancies and allogeneic stem cell transplantation. In neutropenic patients, it usually involves the lung and causes high mortality rates. The clinical presentation is difficult to distinguish from invasive pulmonary aspergillosis [126, 148]. A reverse halo or atoll sign has been described on computed tomography scans, but is not specific for mucormycosis. Such ring-shaped consolidation surrounding a central infiltrate should prompt a diagnostic work-up including bronchoalveolar lavage and biopsy [30, 49, 185].

Treatment combines surgical debridement and antifungal treatment (AII). Surgery is often necessary to confirm diagnosis and may be used to decrease the fungal burden $[29,54,148$, $167,171]$.

For first-line antifungal treatment, options include a lipidbased amphotericin B formulation or posaconazole. D-AmB yielded inferior results and is nephrotoxic $[29,126,148,167$, $180,[187]$. ABLC treatment was published in small series only $[90,148,167,188]$, while there are a larger number of reports including one series of $\mathrm{L}-\mathrm{AmB}$ treatment for mucormycosis [35, $126,148,154,166,167]$. Posaconazole first-line treatment has been reported in two small series $[154,167]$. In a single series, lipid-based amphotericin $\mathrm{B}$ has been combined with caspofungin for rhino-orbital-cerebral diseases (CIII), a pattern not typical for hematologic but rather for diabetic patients [144].

In second-line treatment, the same drugs were used either for refractory disease or because of intolerance of the patient, i.e., ABLC [90, 188], L-AmB [126], ABCD [67], or posaconazole [54, 167, 181].

Voriconazole is inactive in mucormycosis, and breakthrough infections during voriconazole exposure have been reported from retrospective evaluations and various case reports [103]. However, prospective clinical trials on voriconazole prophylaxis did not confirm an increased incidence [101, 195].

Taken together, most data, including results of multivariate prognostic factor analyses, support the use of L-AmB $5 \mathrm{mg} /$ $\mathrm{kg} /$ day (AII) and doses $>5 \mathrm{up}$ to $10 \mathrm{mg} / \mathrm{kg} /$ day (AIII), while ABLC and posaconazole $4 \times 200 \mathrm{mg}$ /day are recommended with lesser strength (BII) in the first-line treatment. Secondline treatment with posaconazole is recommended (AII), while all three lipid-based amphotericin B formulations are alternatives (BII) (see Table 4). Use of D-AmB is strongly discouraged in any indication and at any dose (EI).

\section{Treatment of cryptococcosis}

The vast majority of clinical studies on treatment of cryptococcosis have been performed in patients with AIDS, albeit patients with hemato-oncological malignancies might also be affected [15, 24, 62]. Infections by Cryptococcus spp.-mainly 
Cryptococcus neoformans or Cryptococcus gattii-commonly involve the CNS, but fungemia or disseminated infections might also occur. Diagnosis is usually based on fungal cultures, India ink smear examination, latex-antigen test, and PCR studies using cerebrospinal fluid. Treatment of CNS cryptococcosis in hematological patients should comprise L-AmB together with flucytosine (5-FC) (AIII), usually followed by maintenance therapy with fluconazole [21, 24, 134] (see Table 5).

Second-line or salvage treatment options for CNS cryptococcosis include L-Amb as single agent (BI), ABLC (5 mg/kg) (BIII), voriconazole (BIII), posaconazole (CIII), D-AmB combined with voriconazole or fluconazole (BII), and voriconazole combined with 5-FC (BII) [12, 60, 97, 120, 165]. Severe cryptococcosis of the lungs or of other organ systems should be treated like CNS cryptococcosis (CIII). Very few and mainly preclinical data are available concerning treatment of cryptococcosis by other agents such as caspofungin or posaconazole. Therefore, these agents should not be used in the clinical routine setting to treat cryptococcosis (Table 6).

\section{Treatment of fusariosis}

Invasive fusariosis is a severe sporadic mold infection affecting mainly neutropenic patients. It is associated with a very high mortality rate of $50-80 \%[28,118,119]$. The skin and the lungs are the most frequent sites of infection, albeit involvement of the sinus, soft tissues, and fungemia or disseminated infections occurs frequently [28]. Systematic prospective analyses on the treatment of Fusarium infections are still lacking. Retrospective case series suggest that L-AmB might be preferable in hematological patients who often receive other nephrotoxic drugs (BII). Voriconazole has been used within the last years with success to treat invasive fusariosis (BII) ([96], Nucci et al. M-1234 ICAAC 2012). Posaconazole (BIII) or ABLC (BIII) might be used as alternative treatment options [28, 96, 118, 133, 135, 139] (see Table 5). Surgical resection of necrotic tissues (e.g., skin), central venous line removal, or in vitro resistance testing might be further

Table 4 Treatment of mucormycosis in hemato-oncological patients

\begin{tabular}{ll}
\hline First-line treatment & \\
Liposomal AmB $(\geq 5 \mathrm{mg} / \mathrm{kg})$ & AII \\
ABLC & BII \\
Posaconazole & BII \\
Lipid-based amphotericin B plus caspofungin & CIII \\
Second-line treatment & \\
Posaconazole & AII \\
Liposomal AmB $(\geq 5 \mathrm{mg} / \mathrm{kg})$ & BII \\
ABLC & BII \\
Additional surgical debridement & AII \\
\hline
\end{tabular}

measures to improve the outcome of patients with invasive fusariosis (CIII).

\section{Treatment of Trichosporon infections}

Trichosporon species underwent different taxonomies and are genetically heterogeneous. Apart from colonization of skin or mucosal membranes, these yeast-like pathogens may cause deep-seated infections, mostly in immunocompromised patients, specifically those with hematologic malignancies.

Regarding treatment, there are no data from randomized trials in cancer patients, and we recommend guiding therapy by susceptibility tests. Conclusions are restricted by the fact that the majority of studies are examining sensitivity with Trichosporon asahii/beigelii; other Trichosporon species were less present and may differ in results.

Clinical data confirm that azoles improve response rates (CIII) [4, 150, 169] and markedly voriconazole (B III) has been used in patients with hematological malignancies [8, 9, 44, 46, 51, 150] (see Table 5). As high MIC values correspond to low response rates in hematological patients receiving amphotericin B [51] or an echinocandin [17, 53, 105], these agents cannot be recommended as monotherapy (DIII). Clinical data to recommend these agents in combination therapy with each other or with an azole are too scarce to establish any recommendation $[14,51,71]$.

\section{Treatment of Scedosporium infections}

Pseudallescheria/Scedosporium species are opportunistic fungal species causing life-threatening disseminated infections in immunocompromised patients [55, 88, 149, 173]. The most common pathogens are Scedosporium prolificans and Scedosporium apiospermum (teleomorph Pseudallescheria boydii). Systemic infections with Scedosporium/Pseudallescheria species are often refractory to treatment as these pathogens are highly resistant to available antifungal agents [37]. No treatment data from randomized trials exist for any patient group, and available information about treatment outcome only stems from case reports and case collections.

S. prolificans Grenouillet and coworkers describe 119 patients with systemic Scedosporium infections. Only 11/119 patients survived, resulting in a death rate of $>90 \%$ [55]. Reviewing the cases of the surviving patients, treatment of systemic scedosporiosis should include a multimodal approach using surgery, if possible, antifungal combination therapy, and supportive measures of immune reconstitution (e.g., growth factor support). Tintelnot and coworkers reported on nine patients with an underlying hematologic malignancy, and all nine died [173]. Taken together, voriconazole plus terbinafine 
seems to give the most promising results (CIII) $[20,55,72$, $114,173,194]$. Another alternative is L-AmB in a dosage of at least $5 \mathrm{mg} / \mathrm{kg}$ (CIII) (see Table 5).

S. apiospermum Reports about S. apiospermum infections are even scarcer. Besides single case reports [13, 38], 21 patients with an underlying hematologic malignancy were reported from MD Anderson Cancer Center, TX [89]. Mortality rate in patients with disseminated $S$. apiospermum infection was $79 \%$. Most survivors received a combination therapy consisting of L-AmB and a triazole (voriconazole, posaconazole). Given these data, the treatment recommendation for $S$. apiospermum infection is L-AmB in a dosage of $5 \mathrm{mg} / \mathrm{kg}$ (BIII) or an azole such as voriconazole or posaconazole (BIII) (see Table 5).

\section{Therapeutic drug monitoring of antifungal agents}

Bioavailability might have an impact on clinical efficacy, and pharmacokinetic properties of antifungal agents vary substantially. For flucytosine with its known association of plasma concentration and toxicity, therapeutic drug monitoring has broadly been established [47]. Meanwhile, several studies investigated triazole concentrations in plasma or serum and correlations with clinical efficacy or toxicity. Most of these analyses are limited to retrospective investigations and nearly all of them focus on Aspergillus infections. In contrast to current triazoles, plasma levels of echinocandins and systemic polyenes are comparatively stable, and sufficient concentrations are supported by obligatory intravenous application. For these classes of

Table 5 Treatment of rare fungal infections in hemato-oncological patients

\begin{tabular}{ll}
\hline Cryptococcus neoformans infections & \\
Liposomal AmB $(3-4 \mathrm{mg} / \mathrm{kg})+5$-FC & AIII \\
Fusariosis & \\
$\quad$ Voriconazole & BII \\
Liposomal AmB $(\geq 5 \mathrm{mg} / \mathrm{kg})$ & $\mathrm{BII}$ \\
ABLC & BIII \\
Scedosporium spp. infections & \\
S. apiospermum $(=$ Pseudallescheria boydii $)$ & \\
$\quad$ Liposomal AmB $(\geq 5 \mathrm{mg} / \mathrm{kg})$ & $\mathrm{BIII}$ \\
$\quad$ Voriconazole & $\mathrm{BIII}$ \\
$\quad$ Posaconazole & BIII \\
S. prolificans & \\
$\quad$ Voriconazole + terbinafin & $\mathrm{CIII}$ \\
$\quad$ Liposomal AmB $(\geq 5 \mathrm{mg} / \mathrm{kg})$ & $\mathrm{CIII}$ \\
Trichosporon spp. infections & \\
Voriconazole & BIII \\
Posaconazole & $\mathrm{CIII}$ \\
\hline
\end{tabular}

antifungal agents, monitoring of drug concentration is not required in general. For fluconazole, efficacy seems also to be associated with dosage and achieved blood concentrations.

Voriconazole plasma concentrations show a broad range of intra- and interindividual variation. This triazole is metabolized at least by the isoenzymes $2 \mathrm{C} 19,2 \mathrm{C} 9$, and $3 \mathrm{~A} 4$ of the cytochrome P450 system, which can cause many potential drug interactions $[64,168]$. In addition, genetic variations of isoenzyme 2C19 alter biodegradation of voriconazole significantly, and other factors including food and absorption may change its bioavailability. Therefore, voriconazole plasma concentrations cannot be predicted by dosage [132].

Small retrospective analyses showed an association between plasma concentrations and clinical response in the treatment of invasive aspergillosis, but also an increased rate of adverse events for high plasma concentrations (usually above 5.0 or $5.5 \mathrm{mg} / \mathrm{l})$ [41, 130, 175, 177]. A retrospective analysis of nine clinical phase I to III trials revealed an association between plasma concentration and clinical response for all invasive fungal infection [176]. This could be demonstrated separately for both Candida and Aspergillus infections. On the basis of these studies, an improved rate of global response can be expected in case of plasma concentrations between 1 and $5.5 \mathrm{mg} / 1$ [176]. The retrospective design and the incomplete documented timing for the drawing of blood samples are major limitations of these investigations. In a small prospective study comparing weight-adjusted voriconazole therapy with drug monitoring-guided voriconazole application for first-line or salvage therapy could not demonstrate a significant difference in the primary endpoint of adverse events [129]. However, although only a rather small number of patients were enrolled, the clinical response was significantly better when voriconazole dosage was adjusted to the determined plasma concentrations. Voriconazole concentrations were determined on day 3 after the start of therapy and always 3 days after change of dosage. When interpreting these results, it has to be kept in mind that the study population consisted of Asians, and azole metabolism enzyme patterns differ in Asians and Caucasians [129].

Posaconazole is currently available as oral solution only. Absorption is limited and doses above $800 \mathrm{mg}$ daily did not increase plasma concentration [179]. Drug interaction, fasting condition, and increased gastric $\mathrm{pH}$, e.g., due to proton pump inhibitor usage, may impair bioavailability $[64,156]$. The initial study of posaconazole for salvage therapy of IA already included a post hoc analysis on the impact of plasma concentration. Patients were divided in quartiles of rising drug concentration, which paralleled global response [189].

In summary, therapeutic drug monitoring for triazoles can be used to improve clinical response (BII). Determination of plasma/serum concentrations of voriconazole and posaconazole should be considered at least in case of suspected breakthrough infection, (suspected) lack of response despite sufficient 
Table 6 Daily doses of antifungal agents for the treatment of IFD

\begin{tabular}{|c|c|c|c|}
\hline & Daily dose & Loading dose day 1 & Dose adjustments \\
\hline Caspofungin & $\begin{array}{l}\text { weight } \leq 80 \mathrm{~kg} ; 50 \mathrm{mg} \\
\text { weight }>80 \mathrm{~kg}: 70 \mathrm{mg}\end{array}$ & $70 \mathrm{mg}$ & Liver cirrhosis: Child-Pugh score B: $35 \mathrm{mg} /$ day; C: no data \\
\hline Micafungin & $100 \mathrm{mg}$ & & \\
\hline Anidulafungin & $100 \mathrm{mg}$ & $200 \mathrm{mg}$ & \\
\hline Liposomal AmB & $3 \mathrm{mg} / \mathrm{kg}$ & & CNS 3-5 mg/kg; mucormycosis $\geq 5 \mathrm{mg} / \mathrm{kg}$ \\
\hline ABLC & $5 \mathrm{mg} / \mathrm{kg}$ & & \\
\hline Voriconazole i.v. & $2 \times 4 \mathrm{mg} / \mathrm{kg}$ & $2 \times 6 \mathrm{mg} / \mathrm{kg}$ & $\begin{array}{l}\text { Creatinine clearance }<50 \mathrm{ml} / \mathrm{min} \text { : preferably } \\
\text { oral administration; liver cirrhosis: see below }\end{array}$ \\
\hline Voriconazole p.o. & $2 \times 200 \mathrm{mg}$ & $2 \times 400 \mathrm{mg}$ & $\begin{array}{l}\text { Consider } 2 \times 300 \mathrm{mg} \text { to obtain plasma levels comparable } \\
\text { with } 4 \mathrm{mg} / \mathrm{kg} \text { i.v.; liver cirrhosis: Child-Pugh score A-B } \\
50 \% \text { dose reduction; C: no data }\end{array}$ \\
\hline Posaconazole & $2 \times 400 \mathrm{mg}$ & & $4 \times 200 \mathrm{mg}$ in case of insufficient enteral nutrition \\
\hline Fluconazole i.v./p.o. & $400-800 \mathrm{mg}$ & $800 \mathrm{mg}$ & Creatinine clearance $11-50 \mathrm{ml} / \mathrm{min}: 50 \%$ dose reduction \\
\hline 5-Flucytosine & $150 \mathrm{mg} / \mathrm{kg}$ divided into 4 doses & & \\
\hline
\end{tabular}

antifungal chemotherapy (adequate dosage, duration $\geq 2$ weeks), suspected drug-related toxicity, switch from intravenous to oral therapy, oral therapy, and limited resorption because of nausea or diarrhea or specific comedications (e.g., proton pump inhibitor in case of posaconazole). For voriconazole, a plasma concentration between 1 and $5 \mathrm{mg} / \mathrm{ml}$ and for posaconazole above $0.7 \mathrm{mg} / \mathrm{ml}$ should be targeted for therapy of invasive fungal infection (BII). Although optimal timing and quantity of determined plasma concentrations have not been sufficiently investigated, trough concentrations in steady state might be appropriate (CIII). For flucytosine, a plasma concentration of 30 to $80 \mathrm{mg} / \mathrm{ml} 2 \mathrm{~h}$ after application is recommended (BII).

\section{Empirical versus preemptive antifungal therapy}

In recent years, there has been controversy about the optimal therapeutic regimen for the initiation of antifungal therapy in the setting of persistent fever in patients with prolonged neutropenia.

Current guidelines recommend the implementation of antifungal therapy in neutropenic patients as soon as there is no defervescence after 3-5 days of treatment with broad-spectrum antibiotic chemotherapy. This so-called empirical antifungal strategy has drawbacks such as potential side effects and costs.

Preemptive treatment is commonly described as a diagnostic-driven therapy (i.e., the diagnostic work-up shows suspicious findings before initiation of antifungal treatment), whereas empirical therapy is often referred to as fever-driven therapy.

Several recent studies compare the diagnostic-driven approach with fever-driven antifungal therapy $[2,33,63$, $158,170]$ : So far, the routine use of the diagnostic-driven approach cannot be recommended as long as the current diagnostic tools lack sensitivity and/or specificity and treatment triggers are not clearly defined. Furthermore, treatment delay might enhance mortality in this patient population.

Some of these studies used microbiological tools for the monitoring of fungal disease, e.g., fungal PCR techniques, serum galactomannan, or $\beta$-D-glucan testing; some studies asked for specific radiological signs such as a halo sign as trigger for initiating preemptive antifungal therapy. The polymerase chain reaction based-preemptive antifungal therapy creates a major difficulty, as this method is not yet established as a standard diagnostic for fungal infections. The assessment of outcomes was different and shows the difficulty in dealing with therapeutic strategies: some studies used survival of the invasive fungal infection as the information of choice, whereas others investigated the consumption and costs of antifungal treatment.

In order to use a diagnostic-driven therapeutic approach, a stringent assessment of clinical signs and symptoms and microbiological and radiological diagnostics must be warranted (BIII), e.g., monitoring of galactomannan at least twice weekly, performance of high-resolution computed tomography of the chest and the paranasal sinuses in persistent fever despite adequate antibacterial antibiotic chemotherapy, and regular clinical examination of the patient.

\section{Interventional strategies}

Surgical intervention

Potential indications for a surgical intervention in pulmonary fungal infection might be (1) acute hemoptysis, (2) need of 
histological diagnostics, (3) removal of residual infiltrates prior to the next chemotherapy cycle, (4) prevention of bleeding in the case of fungal lesions with vessel involvement, and (5) reduction of fungal burden (e.g., in mucormycosis).

Hemoptysis occurs in pulmonary aspergillosis or mucormycosis in up to $30 \%$ of the cases, frequently during the phase of neutrophil recovery. The resection of residual infiltrations, combined with antifungal therapy, may result in a local control of the fungal infection in patients requiring further intensive chemotherapy or transplantation [117]. A monocenter study found a reduction in mortality from 41 to $14 \%$ after introduction of systemic computed tomography (CT) examinations followed by frequent use of surgical resections when compared to a historical control [25]. In another study comprising 41 patients with hematologic diseases undergoing surgical intervention of their IPA, the mortality within 30 days was about $10 \%$, fungal relapse occurred in $10 \%$, and the overall survival at 6 months was $65 \%$ [106]. Danner et al. reviewed 198 patients having undergone surgery for IPA. They found a day-30 mortality of $12 \%$ and a 6-month survival of $50 \%$ [39].

However, experience in surgical treatment of IPA is based on data from the era of D-AmB. With the newer antifungal agents, surgical intervention seems to have less importance. Therefore, we recommend surgical resections for the above-listed circumstances in accordance to other guidelines [186] (BII).

In sinu-nasal aspergillosis, additional surgical intervention may be necessary in individual cases (BII) [186]. In aspergillosis of the CNS, surgical resection should be considered (AII) as it seems to improve outcome [160].

\section{Drug instillation}

For treatment of refractory abscesses or caverns (e.g., in the lung or brain) in which surgical intervention is not feasible, a drainage as well as a local drug instillation may be considered. Here, antifungal preparations (commonly containing AmB) or disinfecting substances such as sodium iodide or potassium iodide can be administered (CIII) [197].

\section{Embolization}

Embolization may be considered in the case of large pulmonary infiltrates where the occurrence of hemoptysis due to vessel erosion is likely, including the development of aneurysms. The vessel involvement of fungal lesions should be diagnosed by a spiral CT. If confirmed, the bronchial and pulmonary vessels can be embolized (CIII) [69].

\section{Immunotherapy and granulocyte transfusion}

Colony-stimulating factors The application of hematopoietic growth factor should be considered on an individual case-by- case basis, according to the recommendations of the EORTC (B III) [1].

Tcell therapy A study from the Perugia group showed a more rapid reduction in the galactomannan antigen titer and a better outcome in patients with IPA after haplo-identical stem cell transplantation, when receiving $\mathrm{T}$ cells raised against fungal pathogens [136]. Further studies with the transfer of immune effector cells and better tools to determine the numbers of fungus-specific $\mathrm{T}$ cells prior and after cellular immunotherapy are urgently required. So far, this kind of therapeutic option is still considered experimental.

Granulocyte transfusions Compared to the 1980s, granulocyte harvest and granulocyte function have clearly improved by stimulating donors with G-CSF [137]. Presently, interventional granulocyte transfusions are being studied in clinical trials. In a retrospective case-controlled study on 74 stem cell transplant patients, there was a tendency toward worse outcome in the transfused patients [73]. Another case-controlled study in patients with candidemia showed an equal short-term survival rate, but the group with granulocyte transfusions had higher risk factors which may be interpreted as a benefit of this option [155]. In 31 patients with invasive fungal infection (17 possible infections) undergoing granulocyte transfusions, $78 \%$ survived [113].

A randomized study with prophylactic granulocyte transfusion thrice a week in patients with neutropenic fever and pulmonary infiltrates or a history of proven IFD failed to confirm the benefit of this procedure [164]. Currently, clear benefit of granulocyte transfusions in invasive mycoses has not been doubtlessly clarified [137]. However, it might be considered as a treatment option in selected patients (CIII).

Conflict of interest SM was a consultant to MSD; served at the speakers' bureau of MSD and Pfizer; and received travel grants from MSD, Astellas, Gilead Sciences, and Pfizer.

DB is consultant to Gilead Sciences; received research grants from Gilead Sciences and Pfizer; served on the speakers' bureau of Astellas, Gilead Sciences, Merck Sharp \& Dohme/Merck, and Pfizer; and received travel grants from Astellas, Merck Sharp \& Dohme/Merck, and Pfizer.

WH has received research grants from Astellas, Basilea, Gilead, MSD/Merck (previously Essex/Schering-Plough), and Pfizer and has served as a speaker for Cephalon, Gilead, MSD/Merck, and Pfizer.

MR has received research grants from Deutsche Krebshilfe/German Cancer Aid, Pfizer, and Merck/MSD; is a consultant to Astellas, Basilea, Essex/Schering-Plough, Gilead Sciences, Janssen, Merck/MSD, Novartis, Pfizer, and Pliva; and served at the speakers' bureau of Gilead Sciences, Merck/MSD, and Pfizer.

OAC is supported by the German Federal Ministry of Research and Education (BMBF grant 01KN1106) and has received research grants from, is an advisor to, or received lecture honoraria from $3 \mathrm{M}$, Actelion, Astellas, Basilea, Bayer, Celgene, Cubist, F2G, Genzyme, Gilead, GSK, Merck/ MSD, Miltenyi, Optimer, Pfizer, Quintiles, Sanofi Pasteur, and Viropharma. 
GE was a consultant to MSD, served at the speakers' bureau of MSD and Pfizer, and received travel grants from MSD.

SN was a consultant to MSD and served at the speakers' bureau of MSD and Gilead Sciences.

HO received research grants from MSD and Gilead Sciences; served on the speakers' bureau of Gilead, Pfizer, and MSD; and was a consultant to MSD, Gilead, and Astellas.

JP is consultant to MSD; served at the speakers' bureau of MSD and Gilead; and received travel grants from MSD, Astellas, Gilead, and Pfizer.

OP received research support from Fresenius Biotech, Bio Rad, Pierre Fabre Pharma GmbH, and Gilead; served at the speakers' bureau of MSD, Astellas, Gilead; and has been an advisory board of MSD.

CR served for the speakers' bureau of Gilead Sciences, Pfizer International, and MSD.

MSH served at the speaker's bureau of Gilead Sciences.

GS was a consultant to MSD, served at the speakers' bureau of MSD and Pfizer, and received travel grants from MSD, Astellas, Essex/ Schering-Plough, Gilead Sciences, Janssen, and Pfizer.

AJU received research grants from MSD, Pfizer, and Schering-Plough and has served as a consultant to and has been on the speaker's bureau of Astellas, Basilea, Gilead, MSD, Pfizer, and Schering-Plough.

GM has served as a consultant and has been on the speakers' bureau for Gilead Sciences, MSD, and Pfizer.

$\mathrm{AB}$ has received research grant from Basilea, Astellas, Pfizer, and Essex/MSD; is a consultant to MSD and Gilead Sciences; and served at the speaker's bureau of MSD.

WK, HL, TS, and HHW have no conflicts of interest.

Open Access This article is distributed under the terms of the Creative Commons Attribution License which permits any use, distribution, and reproduction in any medium, provided the original author(s) and the source are credited.

\section{References}

1. Aapro MS, Bohlius J, Cameron DA, Dal Lago L, Donnelly JP, Kearney N, Lyman GH, Pettengell R, Tjan-Heijnen VC, Walewski J, Weber DC, Zielinski C (2011) 2010 update of EORTC guidelines for the use of granulocyte-colony stimulating factor to reduce the incidence of chemotherapy-induced febrile neutropenia in adult patients with lymphoproliferative disorders and solid tumours. Eur J Cancer 47:8-32

2. Aguilar-Guisado M, Martin-Pena A, Espigado I, Perez R, de Pipaon M, Falantes J, de la Cruz F, Cisneros JM (2011) Universal antifungal therapy is not needed in persistent febrile neutropenia: a tailored diagnostic and therapeutic approach. Haematologica 97:464-471

3. Anaissie E, Bodey GP, Kantarjian H, David C, Barnett K, Bow E, Defelice R, Downs N, File T, Karam G (1991) Fluconazole therapy for chronic disseminated candidiasis in patients with leukemia and prior amphotericin B therapy. Am J Med 91:142-150

4. Anaissie E, Gokaslan A, Hachem R, Rubin R, Griffin G, Robinson R, Sobel J, Bodey G (1992) Azole therapy for trichosporonosis: clinical evaluation of eight patients, experimental therapy for murine infection, and review. Clin Infect Dis 15:781-787

5. Anaissie EJ, Darouiche RO, Abi-Said D, Uzun O, Mera J, Gentry LO, Williams T, Kontoyiannis DP, Karl CL, Bodey GP (1996) Management of invasive candidal infections: results of a prospective, randomized, multicenter study of fluconazole versus amphotericin B and review of the literature. Clin Infect Dis 23:964-972

6. Anaissie EJ, Rex JH, Uzun O, Vartivarian S (1998) Predictors of adverse outcome in cancer patients with candidemia. Am J Med 104:238-245
7. Anaissie EJ, Vartivarian SE, Abi-Said D, Uzun O, Pinczowski H, Kontoyiannis DP, Khoury P, Papadakis K, Gardner A, Raad I, Gilbreath J, Bodey GP (1996) Fluconazole versus amphotericin B in the treatment of hematogenous candidiasis: a matched cohort study. Am J Med 101:170-176

8. Antachopoulos C, Papakonstantinou E, Dotis J, Bibashi E, Tamiolaki M, Koliouskas D, Roilides E (2005) Fungemia due to Trichosporon asahii in a neutropenic child refractory to amphotericin B: clearance with voriconazole. J Pediatr Hematol Oncol 27:283-285

9. Asada N, Uryu H, Koseki M, Takeuchi M, Komatsu M, Matsue K (2006) Successful treatment of breakthrough Trichosporon asahii fungemia with voriconazole in a patient with acute myeloid leukemia. Clin Infect Dis 43:e39-e41

10. Ascioglu S, Rex JH, de Pauw B, Bennett JE, Bille J, Crokaert F, Denning DW, Donnelly JP, Edwards JE, Erjavec Z, Fiere D, Lortholary O, Maertens J, Meis JF, Patterson TF, Ritter J, Selleslag D, Shah PM, Stevens DA, Walsh TJ, Invasive Fungal Infections Cooperative Group of the European Organization for R, Treatment of C, Mycoses Study Group of the National Institute of A, Infectious D (2002) Defining opportunistic invasive fungal infections in immunocompromised patients with cancer and hematopoietic stem cell transplants: an international consensus. Clin Infect Dis 34:7-14

11. Baddley JW, Andes DR, Marr KA, Kontoyiannis DP, Alexander BD, Kauffman CA, Oster RA, Anaissie EJ, Walsh TJ, Schuster MG, Wingard JR, Patterson TF, Ito JI, Williams OD, Chiller T, Pappas PG (2010) Factors associated with mortality in transplant patients with invasive aspergillosis. Clin Infect Dis 50:1559-1567

12. Bandettini R, Castagnola E, Calvillo M, Micalizzi C, Ravegnani M, Pescetto L, Manzitti C, Soro O, Ricagni L, Lanino E, Miano M, Cuzzubbo D, Conte M, Morreale G, Faraci M (2009) Voriconazole for cryptococcal meningitis in children with leukemia or receiving allogeneic hemopoietic stem cell transplant. J Chemother 21:108-109

13. Barbaric D, Shaw PJ (2001) Scedosporium infection in immunocompromised patients: successful use of liposomal amphotericin B and itraconazole. Med Pediatr Oncol 37:122-125

14. Bassetti M, Bisio F, Di Biagio A, Pierri I, Balocco M, Soro O, Cruciani M, Bassetti D (2004) Trichosporon asahii infection treated with caspofungin combined with liposomal amphotericin B. J Antimicrob Chemother 54:575-577

15. Bassetti M, Repetto E, Mikulska M, Miglino M, Clavio M, Gobbi M, Righi E, Viscoli C (2009) Cryptococcus neoformans fatal sepsis in a chronic lymphocytic leukemia patient treated with alemtuzumab: case report and review of the literature. J Chemother 21:211-214

16. Bates DW, Su L, Yu DT, Chertow GM, Seger DL, Gomes DR, Dasbach EJ, Platt R (2001) Mortality and costs of acute renal failure associated with amphotericin B therapy. Clin Infect Dis 32:686-693

17. Bayramoglu G, Sonmez M, Tosun I, Aydin K, Aydin F (2008) Breakthrough Trichosporon asahii fungemia in neutropenic patient with acute leukemia while receiving caspofungin. Infection 36:68-70

18. Benjamin DK Jr, Miro JM, Hoen B, Steinbach WJ, Fowler VG Jr, Olaison L, Habib G, Abrutyn E, Perfect J, Zass A, Corey GR, Eykyn S, Thuny F, Jimenez-Exposito MJ, Cabell CH (2004) Candida endocarditis: contemporary cases from the International Collaboration of Infectious Endocarditis Merged Database (ICE$\mathrm{mD})$. Scand J Infect Dis 36:453-455

19. Betts RF, Nucci M, Talwar D, Gareca M, Queiroz-Telles F, Bedimo RJ, Herbrecht R, Ruiz-Palacios G, Young JA, Baddley JW, Strohmaier KM, Tucker KA, Taylor AF, Kartsonis NA (2009) A multicenter, double-blind trial of a high-dose caspofungin treatment regimen versus a standard caspofungin treatment regimen for adult patients with invasive candidiasis. Clin Infect Dis 48:1676-1684

20. Bhat SV, Paterson DL, Rinaldi MG, Veldkamp PJ (2007) Scedosporium prolificans brain abscess in a patient with chronic granulomatous disease: successful combination therapy with voriconazole and terbinafine. Scand J Infect Dis 39:87-90 
21. Bicanic T, Wood R, Meintjes G, Rebe K, Brouwer A, Loyse A, Bekker LG, Jaffar S, Harrison T (2008) High-dose amphotericin B with flucytosine for the treatment of cryptococcal meningitis in HIVinfected patients: a randomized trial. Clin Infect Dis 47:123-130

22. Blumberg HM, Jarvis WR, Soucie JM, Edwards JE, Patterson JE, Pfaller MA, Rangel-Frausto MS, Rinaldi MG, Saiman L, Wiblin RT, Wenzel RP (2001) Risk factors for candidal bloodstream infections in surgical intensive care unit patients: the NEMIS prospective multicenter study. The National Epidemiology of Mycosis Survey. Clin Infect Dis 33:177-186

23. Bow EJ, Loewen R, Cheang MS, Schacter B (1995) Invasive fungal disease in adults undergoing remission-induction therapy for acute myeloid leukemia: the pathogenetic role of the antileukemic regimen. Clin Infect Dis 21:361-369

24. Brouwer AE, Rajanuwong A, Chierakul W, Griffin GE, Larsen RA, White NJ, Harrison TS (2004) Combination antifungal therapies for HIV-associated cryptococcal meningitis: a randomised trial. Lancet 363:1764-1767

25. Caillot D, Casasnovas O, Bernard A, Couaillier JF, Durand C, Cuisenier B, Solary E, Piard F, Petrella T, Bonnin A, Couillault G, Dumas M, Guy H (1997) Improved management of invasive pulmonary aspergillosis in neutropenic patients using early thoracic computed tomographic scan and surgery. J Clin Oncol 15:139-147

26. Caillot D, Couaillier JF, Bernard A, Casasnovas O, Denning DW, Mannone L, Lopez J, Couillault G, Piard F, Vagner O, Guy H (2001) Increasing volume and changing characteristics of invasive pulmonary aspergillosis on sequential thoracic computed tomography scans in patients with neutropenia. J Clinical Oncol Off J Am Soc Clin Oncol 19:253-259

27. Caillot D, Thiebaut A, Herbrecht R, de Botton S, Pigneux A, Bernard F, Larche J, Monchecourt F, Alfandari S, Mahi L (2007) Liposomal amphotericin B in combination with caspofungin for invasive aspergillosis in patients with hematologic malignancies: a randomized pilot study (Combistrat trial). Cancer 110:2740-2746

28. Campo M, Lewis RE, Kontoyiannis DP (2010) Invasive fusariosis in patients with hematologic malignancies at a cancer center: 1998 2009. J Infect 60:331-337

29. Chakrabarti A, Chatterjee SS, Das A, Panda N, Shivaprakash MR, Kaur A, Varma SC, Singhi S, Bhansali A, Sakhuja V (2009) Invasive zygomycosis in India: experience in a tertiary care hospital. Postgrad Med J 85:573-581

30. Chamilos G, Marom EM, Lewis RE, Lionakis MS, Kontoyiannis DP (2005) Predictors of pulmonary zygomycosis versus invasive pulmonary aspergillosis in patients with cancer. Clin Infect Dis 41:60-66

31. Chandrasekar PH, Ito JI (2005) Amphotericin B lipid complex in the management of invasive aspergillosis in immunocompromised patients. Clin Infect Dis 40(Suppl 6):S392-S400

32. Cordonnier C, Bresnik M, Ebrahimi R (2007) Liposomal amphotericin B (AmBisome) efficacy in confirmed invasive aspergillosis and other filamentous fungal infections in immunocompromised hosts: a pooled analysis. Mycoses 50:205-209

33. Cordonnier C, Pautas C, Maury S, Vekhoff A, Farhat H, Suarez F, Dhédin N, Isnard F, Ades L, Kuhnowski F, Foulet F, Kuentz M, Maison P, Bretagne S, Schwarzinger M (2009) Empirical versus preemptive antifungal therapy for high-risk, febrile, neutropenic patients: a randomized, controlled trial. Clin Infect Dis 48:1042-1051

34. Cornely OA, Lasso M, Betts R, Klimko N, Vazquez J, Dobb G, Velez J, Williams-Diaz A, Lipka J, Taylor A, Sable C, Kartsonis N (2007) Caspofungin for the treatment of less common forms of invasive candidiasis. J Antimicrob Chemother 60:363-369

35. Cornely OA, Maertens J, Bresnik M, Ebrahimi R, Ullmann AJ, Bouza E, Heussel CP, Lortholary O, Rieger C, Boehme A, Aoun M, Horst HA, Thiebaut A, Ruhnke M, Reichert D, Vianelli N, Krause SW, Olavarria E, Herbrecht R (2007) Liposomal amphotericin B as initial therapy for invasive mold infection: a randomized trial comparing a high-loading dose regimen with standard dosing (AmBiLoad trial). Clin Infect Dis 44:1289-1297

36. Cornely OA, Vehreschild JJ, Vehreschild MJ, Wurthwein G, Arenz D, Schwartz S, Heussel CP, Silling G, Mahne M, Franklin J, Harnischmacher U, Wilkens A, Farowski F, Karthaus M, Lehrnbecher T, Ullmann AJ, Hallek M, Groll AH (2011) Phase II dose escalation study of caspofungin for invasive aspergillosis. Antimicrob Agents Chemother 55:5798-5803

37. Cortez KJ, Roilides E, Quiroz-Telles F, Meletiadis J, Antachopoulos C, Knudsen T, Buchanan W, Milanovich J, Sutton DA, Fothergill A, Rinaldi MG, Shea YR, Zaoutis T, Kottilil S, Walsh TJ (2008) Infections caused by Scedosporium spp. Clin Microbiol Rev 21:157197

38. Cunningham R, Mitchell DC (1996) Amphotericin B responsive Scedosporium apiospermum infection in a patient with acute myeloid leukaemia. J Clin Pathol 49:93-94

39. Danner BC, Didilis V, Dorge H, Mikroulis D, Bougioukas G, Schondube FA (2008) Surgical treatment of pulmonary aspergillosis/mycosis in immunocompromised patients. Interact Cardiovasc Thorac Surg 7:771-776

40. Denning DW, Marr KA, Lau WM, Facklam DP, Ratanatharathorn V, Becker C, Ullmann AJ, Seibel NL, Flynn PM, van Burik JA, Buell DN, Patterson TF (2006) Micafungin (FK463), alone or in combination with other systemic antifungal agents, for the treatment of acute invasive aspergillosis. J Infect 53:337-349

41. Denning DW, Ribaud P, Milpied N, Caillot D, Herbrecht R, Thiel E, Haas A, Ruhnke M, Lode H (2002) Efficacy and safety of voriconazole in the treatment of acute invasive aspergillosis. Clin Infect Dis 34:563-571

42. deShazo RD, Chapin K, Swain RE (1997) Fungal sinusitis. N Engl J Med 337:254-259

43. Ellis M, Spence D, de Pauw B, Meunier F, Marinus A, Collette L, Sylvester R, Meis J, Boogaerts M, Selleslag D, Krcmery V, von Sinner W, MacDonald P, Doyen C, Vandercam B (1998) An EORTC international multicenter randomized trial (EORTC number 19923) comparing two dosages of liposomal amphotericin B for treatment of invasive aspergillosis. Clin Infect Dis 27:1406-1412

44. Falk R, Wolf DG, Shapiro M, Polacheck I (2003) Multidrugresistant Trichosporon asahii isolates are susceptible to voriconazole. J Clin Microbiol 41:911

45. Flattery AM, Hickey E, Gill CJ, Powles MA, Misura AS, Galgoci AM, Ellis JD, Zhang R, Sandhu P, Ronan J, Abruzzo GK (2011) Efficacy of caspofungin in a juvenile mouse model of central nervous system candidiasis. Antimicrob Agents Chemother 55:3491-3497

46. Fournier S, Pavageau W, Feuillhade M, Deplus S, Zagdanski AM, Verola O, Dombret H, Molina JM (2002) Use of voriconazole to successfully treat disseminated Trichosporon asahii infection in a patient with acute myeloid leukaemia. Eur J Clin Microbiol Infect Dis 21:892-896

47. Francis P, Walsh TJ (1992) Evolving role of flucytosine in immunocompromised patients: new insights into safety, pharmacokinetics, and antifungal therapy. Clin Infect Dis 15:1003-1018

48. Garey KW, Rege M, Pai MP, Mingo DE, Suda KJ, Turpin RS, Bearden DT (2006) Time to initiation of fluconazole therapy impacts mortality in patients with candidemia: a multi-institutional study. Clin Infect Dis 43:25-31

49. Georgiadou SP, Sipsas NV, Marom EM, Kontoyiannis DP (2011) The diagnostic value of halo and reversed halo signs for invasive mold infections in compromised hosts. Clin Infect Dis 52:1144-1155

50. Ghosal A, Hapangama N, Yuan Y, Achanfuo-Yeboah J, Iannucci R, Chowdhury S, Alton K, Patrick JE, Zbaida S (2004) Identification of human UDP-glucuronosyltransferase enzyme(s) responsible for the glucuronidation of posaconazole (Noxafil). Drug Metab Dispos $32: 267-271$

51. Girmenia C, Pagano L, Martino B, D’Antonio D, Fanci R, Specchia G, Melillo L, Buelli M, Pizzarelli G, Venditti M, Martino P (2005) 
Invasive infections caused by Trichosporon species and Geotrichum capitatum in patients with hematological malignancies: a retrospective multicenter study from Italy and review of the literature. J Clin Microbiol 43:1818-1828

52. Glasmacher A, Cornely OA, Orlopp K, Reuter S, Blaschke S, Eichel M, Silling G, Simons B, Egerer G, Siemann M, Florek M, Schnitzler R, Ebeling P, Ritter J, Reinel H, Schutt P, Fischer H, Hahn C, Just-Nuebling G (2006) Caspofungin treatment in severely ill, immunocompromised patients: a case-documentation study of 118 patients. J Antimicrob Chemother 57:127-134

53. Goodman D, Pamer E, Jakubowski A, Morris C, Sepkowitz K (2002) Breakthrough trichosporonosis in a bone marrow transplant recipient receiving caspofungin acetate. Clin Infect Dis 35:E35-E36

54. Greenberg RN, Anstead G, Herbrecht R, Langston A, Marr K, Mullane K, Raad I, Schiller G, Schuster M, van Burik JA, Wingard JR, Hare R, Corcoran G (2003) Posaconazole therapy for refractory invasive zygomycosis. In: 43rd Annual Interscience Conference on Antimicrobial Agents and Chemotherapy (ICAAC). Chicago, III, p 476

55. Grenouillet F, Botterel F, Crouzet J, Larosa F, Hicheri Y, Forel JM, Helias P, Ranque S, Delhaes L (2009) Scedosporium prolificans: an emerging pathogen in France? Med Mycol 47:343-350

56. Groll AH, Gea-Banacloche JC, Glasmacher A, Just-Nuebling G, Maschmeyer G, Walsh TJ (2003) Clinical pharmacology of antifungal compounds. Infect Dis Clin North Am 17:159-191, ix

57. Groll AH, Giri N, Petraitis V, Petraitiene R, Candelario M, Bacher JS, Piscitelli SC, Walsh TJ (2000) Comparative efficacy and distribution of lipid formulations of amphotericin B in experimental Candida albicans infection of the central nervous system. J Infect Dis 182:274-282

58. Hachem RY, Boktour MR, Hanna HA, Husni RN, Torres HA, Afif C, Kontoyiannis DP, Raad II (2008) Amphotericin B lipid complex versus liposomal amphotericin B monotherapy for invasive aspergillosis in patients with hematologic malignancy. Cancer 112:1282-1287

59. Hachem RY, Kontoyiannis DP, Boktour MR, Afif C, Cooksley C, Bodey GP, Chatzinikolaou I, Perego C, Kantarjian HM, Raad II (2004) Aspergillus terreus: an emerging amphotericin B-resistant opportunistic mold in patients with hematologic malignancies. Cancer 101:1594-1600

60. Hamill RJ, Sobel JD, El-Sadr W, Johnson PC, Graybill JR, Javaly K, Barker DE (2010) Comparison of 2 doses of liposomal amphotericin B and conventional amphotericin B deoxycholate for treatment of AIDS-associated acute cryptococcal meningitis: a randomized, double-blind clinical trial of efficacy and safety. Clin Infect Dis 51:225-232

61. Harbarth S, Pestotnik SL, Lloyd JF, Burke JP, Samore MH (2001) The epidemiology of nephrotoxicity associated with conventional amphotericin B therapy. Am J Med 111(7):528-534

62. Heath JL, Yin DE, Wechsler DS, Turner DA (2012) Successful treatment of disseminated cryptococcal infection in a pediatric acute lymphoblastic leukemia patient during induction. J Pediatr Hematol Oncol 34:e161-e163

63. Hebart H, Klingspor L, Klingebiel T, Loeffler J, Tollemar J, Ljungman $\mathrm{P}$, Wandt $\mathrm{H}$, Schaefer-Eckart K, Dornbusch HJ, Meisner C, Engel C, Stenger N, Mayer T, Ringden O, Einsele H (2009) A prospective randomized controlled trial comparing PCRbased and empirical treatment with liposomal amphotericin B in patients after allo-SCT. Bone Marrow Transplant 43:553-561

64. Heinz Werner J, Klinker H (2012) Therapeutisches Drug Monitoring von Antimykotika/Therapeutic drug monitoring of antifungal agents. In: Laboratoriumsmedizin. p 99

65. Herbrecht R, Denning DW, Patterson TF, Bennett JE, Greene RE, Oestmann JW, Kern WV, Marr KA, Ribaud P, Lortholary O, Sylvester R, Rubin RH, Wingard JR, Stark P, Durand C, Caillot D, Thiel E, Chandrasekar PH, Hodges MR, Schlamm HT, Troke PF, de Pauw B (2002) Voriconazole versus amphotericin B for primary therapy of invasive aspergillosis. N Engl J Med 347:408-415
66. Herbrecht R, Flückiger U, Gachot B, Ribaud P, Thiebaut A, Cordonnier C (2007) Treatment of invasive Candida and invasive Aspergillus infections in adult haematological patients. Eur $\mathrm{J}$ Cancer Suppl 5:49-59

67. Herbrecht R, Letscher-Bru V, Bowden RA, Kusne S, Anaissie EJ, Graybill JR, Noskin GA, Oppenheim AE, Pietrelli LA (2001) Treatment of 21 cases of invasive mucormycosis with amphotericin B colloidal dispersion. Eur J Clin Microbiol Infect Dis 20:460-466

68. Herbrecht R, Maertens J, Baila L, Aoun M, Heinz W, Martino R, Schwartz S, Ullmann AJ, Meert L, Paesmans M, Marchetti O, Akan H, Ameye L, Shivaprakash M, Viscoli C (2010) Caspofungin first-line therapy for invasive aspergillosis in allogeneic hematopoietic stem cell transplant patients: an European Organisation for Research and Treatment of Cancer study. Bone Marrow Transplant 45:1227-1233

69. Heussel CP, Kauczor HU, Heussel G, Mildenberger P, Dueber C (1997) Aneurysms complicating inflammatory diseases in immunocompromised hosts: value of contrast-enhanced CT. Eur Radiol 7:316-319

70. Hong XY, Chou YC, Lazareff JA (2008) Brain stem candidiasis mimicking cerebellopontine angle tumor. Surg Neurol 70:87-91

71. Hosokawa K, Yamazaki H, Mochizuki K, Ohata K, Ishiyama K, Hayashi T, Kondo Y, Sugimori N, Okumura H, Takami A, Nakao S (2012) Successful treatment of Trichosporon fungemia in a patient with refractory acute myeloid leukemia using voriconazole combined with liposomal amphotericin B. Transpl Infect Dis 14:184-187

72. Howden BP, Slavin MA, Schwarer AP, Mijch AM (2003) Successful control of disseminated Scedosporium prolificans infection with a combination of voriconazole and terbinafine. Eur J Clin Microbiol Infect Dis 22:111-113

73. Hübel K, Carter RA, Liles WC, Dale DC, Price TH, Bowden RA, Rowley SD, Chauncey TR, Bensinger WI, Boeckh M (2002) Granulocyte transfusion therapy for infections in candidates and recipients of HPC transplantation: a comparative analysis of feasibility and outcome for community donors versus related donors. Transfusion 42:1414-1421

74. Ito JI, Chandrasekar PH, Hooshmand-Rad R (2005) Effectiveness of amphotericin B lipid complex (ABLC) treatment in allogeneic hematopoietic cell transplant (HCT) recipients with invasive aspergillosis (IA). Bone Marrow Transplant 36:873-877

75. Ito JI, Hooshmand-Rad R (2005) Treatment of Candida infections with amphotericin B lipid complex. Clin Infect Dis 40(Suppl 6):S384-S391

76. Jacobs F, Selleslag D, Aoun M, Sonet A, Gadisseur A (2012) An observational efficacy and safety analysis of the treatment of acute invasive aspergillosis using voriconazole. Eur J Clin Microbiol Infect Dis 31:1173-1179

77. Kaffarnik M, Utzolino S, Blaich A, Hopt UT (2008) Successful multimodal therapy of invasive pulmonary and central nervous system aspergillosis in a neutropenic surgical patient: case report and review of the literature. Mycoses 51:74-78

78. Karthaus M, Hebart H, Einsele H, Schaefer H, Scheel-Walter H, Buchheidt D, Lehrnbecher T (2006) Long-term survival in patients with acute leukemia and chronic disseminated candidiasis despite minimal antileukemic therapy. Haematologica 91:1422-1423

79. Kauffman CA, Bradley SF, Ross SC, Weber DR (1991) Hepatosplenic candidiasis: successful treatment with fluconazole. Am J Med 91:137-141

80. Kish MA (2001) Guide to development of practice guidelines. Clin Infect Dis 32:851-854

81. Kontoyiannis DP, Lewis RE (2003) Combination chemotherapy for invasive fungal infections: what laboratory and clinical studies tell us so far. Drug Resist Updat 6:257-269

82. Kontoyiannis DP, Ratanatharathorn V, Young JA, Raymond J, Laverdiere M, Denning DW, Patterson TF, Facklam D, Kovanda L, Arnold L, Lau W, Buell D, Marr KA (2009) Micafungin alone or in combination with other systemic antifungal therapies in 
hematopoietic stem cell transplant recipients with invasive aspergillosis. Transpl Infect Dis 11:89-93

83. Kontoyiannis DP, Reddy BT, Hanna H, Bodey GP, Tarrand J, Raad I (2002) Breakthrough candidemia in patients with cancer differs from de novo candidemia in host factors and Candida species but not intensity. Infect Control Hosp Epidemiol 23:542-545

84. Kuhn DM, George T, Chandra J, Mukherjee PK, Ghannoum MA (2002) Antifungal susceptibility of Candida biofilms: unique efficacy of amphotericin B lipid formulations and echinocandins. Antimicrob Agents Chemothe 46:1773-1780

85. Kullberg BJ, Sobel JD, Ruhnke M, Pappas PG, Viscoli C, Rex JH, Cleary JD, Rubinstein E, Church LW, Brown JM, Schlamm HT, Oborska IT, Hilton F, Hodges MR (2005) Voriconazole versus a regimen of amphotericin B followed by fluconazole for candidaemia in non-neutropenic patients: a randomised noninferiority trial. Lancet 366:1435-1442

86. Kuse ER, Chetchotisakd P, da Cunha CA, Ruhnke M, Barrios C, Raghunadharao D, Sekhon JS, Freire A, Ramasubramanian V, Demeyer I, Nucci M, Leelarasamee A, Jacobs F, Decruyenaere J, Pittet D, Ullmann AJ, Ostrosky-Zeichner L, Lortholary O, Koblinger S, Diekmann-Berndt H, Cornely OA (2007) Micafungin versus liposomal amphotericin B for candidaemia and invasive candidosis: a phase III randomised double-blind trial. Lancet 369:1519-1527

87. Labelle AJ, Micek ST, Roubinian N, Kollef MH (2008) Treatmentrelated risk factors for hospital mortality in Candida bloodstream infections. Crit Care Med 36:2967-2972

88. Lackner M, Rezusta A, Villuendas MC, Palacian MP, Meis JF, Klaassen CH (2011) Infection and colonisation due to Scedosporium in Northern Spain. An in vitro antifungal susceptibility and molecular epidemiology study of 60 isolates. Mycoses 54(Suppl 3):12-21

89. Lamaris GA, Chamilos G, Lewis RE, Safdar A, Raad II, Kontoyiannis DP (2006) Scedosporium infection in a tertiary care cancer center: a review of 25 cases from 1989-2006. Clin Infect Dis 43:1580-1584

90. Larkin JA, Montero JA (2003) Efficacy and safety of amphotericin B lipid complex for zygomycosis. Infect Med 20:201-206

91. Lass-Florl C, Griff K, Mayr A, Petzer A, Gastl G, Bonatti H, Freund M, Kropshofer G, Dierich MP, Nachbaur D (2005) Epidemiology and outcome of infections due to Aspergillus terreus: 10-year single centre experience. Br J Haematol 131:201-207

92. Leenders AC, Daenen S, Jansen RL, Hop WC, Lowenberg B, Wijermans PW, Cornelissen J, Herbrecht R, van der Lelie H, Hoogsteden HC, Verbrugh HA, de Marie S (1998) Liposomal amphotericin B compared with amphotericin B deoxycholate in the treatment of documented and suspected neutropenia-associated invasive fungal infections. Br J Haematol 103:205-212

93. Legrand F, Lecuit M, Dupont B, Bellaton E, Huerre M, Rohrlich PS, Lortholary O (2008) Adjuvant corticosteroid therapy for chronic disseminated candidiasis. Clin Infect Dis 46:696-702

94. Leon C, Ruiz-Santana S, Saavedra P, Almirante B, Nolla-Salas J, Alvarez-Lerma F, Garnacho-Montero J, Leon MA (2006) A bedside scoring system ("Candida score") for early antifungal treatment in nonneutropenic critically ill patients with Candida colonization. Crit Care Med 34:730-737

95. Lin SJ, Schranz J, Teutsch SM (2001) Aspergillosis case-fatality rate: systematic review of the literature. Clin Infect Dis 32:358-366

96. Lortholary O, Obenga G, Biswas P, Caillot D, Chachaty E, Bienvenu AL, Cornet M, Greene J, Herbrecht R, Lacroix C, Grenouillet F, Raad I, Sitbon K, Troke P (2010) International retrospective analysis of 73 cases of invasive fusariosis treated with voriconazole. Antimicrob Agents Chemother 54:4446-4450

97. Loyse A, Wilson D, Meintjes G, Jarvis JN, Bicanic T, Bishop L, Rebe K, Williams A, Jaffar S, Bekker LG, Wood R, Harrison TS (2012) Comparison of the early fungicidal activity of high-dose fluconazole, voriconazole, and flucytosine as second-line drugs given in combination with amphotericin B for the treatment of HIV-associated cryptococcal meningitis. Clin Infect Dis 54:121-128

98. Maertens J, Egerer G, Shin WS, Reichert D, Stek M, Chandwani S, Shivaprakash M, Viscoli C (2010) Caspofungin use in daily clinical practice for treatment of invasive aspergillosis: results of a prospective observational registry. BMC Infect Dis 10:182

99. Maertens J, Glasmacher A, Herbrecht R, Thiebaut A, Cordonnier C, Segal BH, Killar J, Taylor A, Kartsonis N, Patterson TF, Aoun M, Caillot D, Sable C (2006) Multicenter, noncomparative study of caspofungin in combination with other antifungals as salvage therapy in adults with invasive aspergillosis. Cancer 107:2888-2897

100. Maertens J, Raad I, Petrikkos G, Boogaerts M, Selleslag D, Petersen FB, Sable CA, Kartsonis NA, Ngai A, Taylor A, Patterson TF, Denning DW, Walsh TJ (2004) Efficacy and safety of caspofungin for treatment of invasive aspergillosis in patients refractory to or intolerant of conventional antifungal therapy. Clin Infect Dis 39:1563-1571

101. Marks DI, Pagliuca A, Kibbler CC, Glasmacher A, Heussel CP, Kantecki M, Miller PJ, Ribaud P, Schlamm HT, Solano C, Cook G (2011) Voriconazole versus itraconazole for antifungal prophylaxis following allogeneic haematopoietic stem-cell transplantation. Br J Haematol 155:318-327

102. Marr KA, Boeckh M, Carter RA, Kim HW, Corey L (2004) Combination antifungal therapy for invasive aspergillosis. Clin Infect Dis 39:797-802

103. Marty FM, Cosimi LA, Baden LR (2004) Breakthrough zygomycosis after voriconazole treatment in recipients of hematopoietic stem-cell transplants. N Engl J Med 350:950-952

104. Maschmeyer G, Haas A (2006) Defining clinical failure for salvage studies. Med Mycol 44:315-318

105. Matsue K, Uryu H, Koseki M, Asada N, Takeuchi M (2006) Breakthrough trichosporonosis in patients with hematologic malignancies receiving micafungin. Clin Infect Dis 42:753-757

106. Matt P, Bernet F, Habicht J, Gambazzi F, Gratwohl A, Zerkowski HR, Tamm M (2004) Predicting outcome after lung resection for invasive pulmonary aspergillosis in patients with neutropenia. Chest 126:1783-1788

107. Miller CB, Waller EK, Klingemann HG, Dignani MC, Anaissie EJ, Cagnoni PJ, McSweeney P, Fleck PR, Fruchtman SM, McGuirk J, Chao NJ (2004) Lipid formulations of amphotericin B preserve and stabilize renal function in HSCT recipients. Bone Marrow Transplant 33:543-548

108. Mills W, Chopra R, Linch DC, Goldstone AH (1994) Liposomal amphotericin $\mathrm{B}$ in the treatment of fungal infections in neutropenic patients: a single-centre experience of 133 episodes in 116 patients. Br J Haematol 86:754-760

109. Miro JM, del Rio A, Mestres CA (2002) Infective endocarditis in intravenous drug abusers and HIV-1 infected patients. Infect Dis Clin North Am 16:273-295, vii-viii

110. Mora-Duarte J, Betts R, Rotstein C, Colombo AL, ThompsonMoya L, Smietana J, Lupinacci R, Sable C, Kartsonis N, Perfect J (2002) Comparison of caspofungin and amphotericin B for invasive candidiasis. N Engl J Med 347:2020-2029

111. Morrell M, Fraser VJ, Kollef MH (2005) Delaying the empiric treatment of Candida bloodstream infection until positive blood culture results are obtained: a potential risk factor for hospital mortality. Antimicrob Agents Chemother 49:3640-3645

112. Morrissey CO, Slavin MA, O'Reilly MA, Daffy JR, Seymour JF, Schwarer AP, Szer J (2007) Caspofungin as salvage monotherapy for invasive aspergillosis in patients with haematological malignancies or following allogeneic stem cell transplantation: efficacy and concomitant cyclosporin A. Mycoses 50:24-37

113. Mousset S, Hermann S, Klein SA, Bialleck H, Duchscherer M, Bomke B, Wassmann B, Bohme A, Hoelzer D, Martin H (2005) Prophylactic and interventional granulocyte transfusions in patients 
with haematological malignancies and life-threatening infections during neutropenia. Ann Hematol 84:734-741

114. Munoz P, Singh N, Bouza E (2006) Treatment of solid organ transplant patients with invasive fungal infections: should a combination of antifungal drugs be used? Curr Opin Infect Dis 19:365-370

115. Neofytos D, Horn D, Anaissie E, Steinbach W, Olyaei A, Fishman J, Pfaller M, Chang C, Webster K, Marr K (2009) Epidemiology and outcome of invasive fungal infection in adult hematopoietic stem cell transplant recipients: analysis of Multicenter Prospective Antifungal Therapy (PATH) Alliance registry. Clin Infect Dis 48:265-273

116. Nivoix Y, Velten M, Letscher-Bru V, Moghaddam A, NatarajanAme S, Fohrer C, Lioure B, Bilger K, Lutun P, Marcellin L, Launoy A, Freys G, Bergerat JP, Herbrecht R (2008) Factors associated with overall and attributable mortality in invasive aspergillosis. Clin Infect Dis 47:1176-1184

117. Nosari A, Ravini M, Cairoli R, Cozzi P, Marbello L, Marenco P, Grillo G, Morra E (2007) Surgical resection of persistent pulmonary fungus nodules and secondary prophylaxis are effective in preventing fungal relapse in patients receiving chemotherapy or bone marrow transplantation for leukemia. Bone Marrow Transplant 39:631-635

118. Nucci M, Anaissie EJ, Queiroz-Telles F, Martins CA, Trabasso P, Solza C, Mangini C, Simoes BP, Colombo AL, Vaz J, Levy CE, Costa S, Moreira VA, Oliveira JS, Paraguay N, Duboc G, Voltarelli JC, Maiolino A, Pasquini R, Souza CA (2003) Outcome predictors of 84 patients with hematologic malignancies and Fusarium infection. Cancer 98:315-319

119. Nucci M, Marr KA, Queiroz-Telles F, Martins CA, Trabasso P, Costa S, Voltarelli JC, Colombo AL, Imhof A, Pasquini R, Maiolino A, Souza CA, Anaissie E (2004) Fusarium infection in hematopoietic stem cell transplant recipients. Clin Infect Dis 38:1237-1242

120. Nussbaum JC, Jackson A, Namarika D, Phulusa J, Kenala J, Kanyemba C, Jarvis JN, Jaffar S, Hosseinipour MC, Kamwendo D, van der Horst CM, Harrison TS (2010) Combination flucytosine and high-dose fluconazole compared with fluconazole monotherapy for the treatment of cryptococcal meningitis: a randomized trial in Malawi. Clin Infect Dis 50:338-344

121. Ostrosky-Zeichner L, Marr KA, Rex JH, Cohen SH (2003) Amphotericin B: time for a new "gold standard". Clin Infect Dis 37:415-425

122. Pagano L, Caira M, Candoni A, Offidani M, Fianchi L, Martino B, Pastore D, Picardi M, Bonini A, Chierichini A, Fanci R, Caramatti C, Invernizzi R, Mattei D, Mitra ME, Melillo L, Aversa F, Van Lint MT, Falcucci P, Valentini CG, Girmenia C, Nosari A (2006) The epidemiology of fungal infections in patients with hematologic malignancies: the SEIFEM-2004 study. Haematologica 91:10681075

123. Pagano L, Caira M, Candoni A, Offidani M, Martino B, Specchia G, Pastore D, Stanzani M, Cattaneo C, Fanci R, Caramatti C, Rossini F, Luppi M, Potenza L, Ferrara F, Mitra ME, Fadda RM, Invernizzi R, Aloisi T, Picardi M, Bonini A, Vacca A, Chierichini A, Melillo L, de Waure C, Fianchi L, Riva M, Leone G, Aversa F, Nosari A (2010) Invasive aspergillosis in patients with acute myeloid leukemia: a SEIFEM-2008 registry study. Haematologica 95:644-650

124. Pagano L, Caira M, Falcucci P, Fianchi L (2005) Fungal CNS infections in patients with hematologic malignancy. Expert Rev Anti Infect Ther 3:775-785

125. Pagano L, Mele L, Fianchi L, Melillo L, Martino B, D’Antonio D, Tosti ME, Posteraro B, Sanguinetti M, Trape G, Equitani F, Carotenuto M, Leone G (2002) Chronic disseminated candidiasis in patients with hematologic malignancies. Clinical features and outcome of 29 episodes. Haematologica 87:535-541

126. Pagano L, Offidani M, Fianchi L, Nosari A, Candoni A, Piccardi M, Corvatta L, D'Antonio D, Girmenia C, Martino P, Del Favero A
(2004) Mucormycosis in hematologic patients. Haematologica 89:207-214

127. Pappas PG, Kauffman CA, Andes D, Benjamin DK Jr, Calandra TF, Edwards JE Jr, Filler SG, Fisher JF, Kullberg BJ, Ostrosky-Zeichner L, Reboli AC, Rex JH, Walsh TJ, Sobel JD (2009) Clinical practice guidelines for the management of candidiasis: 2009 update by the Infectious Diseases Society of America. Clin Infect Dis 48:503-535

128. Pappas PG, Rotstein CM, Betts RF, Nucci M, Talwar D, De Waele JJ, Vazquez JA, Dupont BF, Horn DL, Ostrosky-Zeichner L, Reboli AC, Suh B, Digumarti R, Wu C, Kovanda LL, Arnold LJ, Buell DN (2007) Micafungin versus caspofungin for treatment of candidemia and other forms of invasive candidiasis. Clin Infect Dis $45: 883-893$

129. Park WB, Kim NH, Kim KH, Lee SH, Nam WS, Yoon SH, Song KH, Choe PG, Kim NJ, Jang IJ, Oh MD, Yu KS (2012) The effect of therapeutic drug monitoring on safety and efficacy of voriconazole in invasive fungal infections: a randomized controlled trial. Clin Infect Dis 55:1080-1087

130. Pascual A, Calandra T, Bolay S, Buclin T, Bille J, Marchetti O (2008) Voriconazole therapeutic drug monitoring in patients with invasive mycoses improves efficacy and safety outcomes. Clin Infect Dis 46:201-211

131. Pascual A, Csajka C, Buclin T, Bolay S, Bille J, Calandra T, Marchetti $O$ (2012) Challenging recommended oral and intravenous voriconazole doses for improved efficacy and safety: population pharmacokinetics-based analysis of adult patients with invasive fungal infections. Clin Infect Dis 55:381-390

132. Pascual A, Nieth V, Calandra T, Bille J, Bolay S, Decosterd LA, Buclin T, Majcherczyk PA, Sanglard D, Marchetti O (2007) Variability of voriconazole plasma levels measured by new highperformance liquid chromatography and bioassay methods. Antimicrob Agents Chemother 51:137-143

133. Perfect JR (2005) Treatment of non-Aspergillus moulds in immunocompromised patients, with amphotericin B lipid complex. Clin Infect Dis 40(Suppl 6):S401-S408

134. Perfect JR, Dismukes WE, Dromer F, Goldman DL, Graybill JR, Hamill RJ, Harrison TS, Larsen RA, Lortholary O, Nguyen MH, Pappas PG, Powderly WG, Singh N, Sobel JD, Sorrell TC (2010) Clinical practice guidelines for the management of cryptococcal disease: 2010 update by the Infectious Diseases Society of America. Clin Infect Dis 50:291-322

135. Perfect JR, Marr KA, Walsh TJ, Greenberg RN, DuPont B, de la Torre-Cisneros J, Just-Nubling G, Schlamm HT, Lutsar I, EspinelIngroff A, Johnson E (2003) Voriconazole treatment for lesscommon, emerging, or refractory fungal infections. Clin Infect Dis 36:1122-1131

136. Perruccio K, Tosti A, Burchielli E, Topini F, Ruggeri L, Carotti A, Capanni M, Urbani E, Mancusi A, Aversa F, Martelli MF, Romani L, Velardi A (2005) Transferring functional immune responses to pathogens after haploidentical hematopoietic transplantation. Blood 106:4397-4406

137. Price TH (2007) Granulocyte transfusion: current status. Semin Hematol 44:15-23

138. Raad II, Graybill JR, Bustamante AB, Cornely OA, Gaona-Flores V, Afif C, Graham DR, Greenberg RN, Hadley S, Langston A, Negroni R, Perfect JR, Pitisuttithum P, Restrepo A, Schiller G, Pedicone L, Ullmann AJ (2006) Safety of long-term oral posaconazole use in the treatment of refractory invasive fungal infections. Clin Infect Dis 42:1726-1734

139. Raad II, Hachem RY, Herbrecht R, Graybill JR, Hare R, Corcoran G, Kontoyiannis DP (2006) Posaconazole as salvage treatment for invasive fusariosis in patients with underlying hematologic malignancy and other conditions. Clin Infect Dis 42:1398-1403

140. Raad II, Hanna HA, Boktour M, Jiang Y, Torres HA, Afif C, Kontoyiannis DP, Hachem RY (2008) Novel antifungal agents as salvage therapy for invasive aspergillosis in patients with 
hematologic malignancies: posaconazole compared with high-dose lipid formulations of amphotericin B alone or in combination with caspofungin. Leukemia 22:496-503

141. Raad I, Hanna H, Boktour M, Girgawy E, Danawi H, Mardani M, Kontoyiannis D, Darouiche R, Hachem R, Bodey GP (2004) Management of central venous catheters in patients with cancer and candidemia. Clin Infect Dis 38:1119-1127

142. Raad I, Hanna H, Maki D (2007) Intravascular catheter-related infections: advances in diagnosis, prevention, and management. Lancet Infect Dis 7:645-657

143. Reboli AC, Rotstein C, Pappas PG, Chapman SW, Kett DH, Kumar D, Betts R, Wible M, Goldstein BP, Schranz J, Krause DS, Walsh TJ (2007) Anidulafungin versus fluconazole for invasive candidiasis. N Engl J Med 356:2472-2482

144. Reed C, Bryant R, Ibrahim AS, Edwards J Jr, Filler SG, Goldberg R, Spellberg B (2008) Combination polyene-caspofungin treatment of rhino-orbital-cerebral mucormycosis. Clin Infect Dis 47:364-371

145. Rex JH, Bennett JE, Sugar AM, Pappas PG, Serody J, Edwards JE, Washburn RG (1995) Intravascular catheter exchange and duration of candidemia NIAID Mycoses Study Group and the Candidemia Study Group. Clin Infect Dis 21:994-996

146. Rex JH, Pappas PG, Karchmer AW, Sobel J, Edwards JE, Hadley S, Brass C, Vazquez JA, Chapman SW, Horowitz HW, Zervos M, McKinsey D, Lee J, Babinchak T, Bradsher RW, Cleary JD, Cohen DM, Danziger L, Goldman M, Goodman J, Hilton E, Hyslop NE, Kett DH, Lutz J, Rubin RH, Scheld WM, Schuster M, Simmons B, Stein DK, Washburn RG, Mautner L, Chu TC, Panzer H, Rosenstein RB, Booth J (2003) A randomized and blinded multicenter trial of high-dose fluconazole plus placebo versus fluconazole plus amphotericin B as therapy for candidemia and its consequences in nonneutropenic subjects. Clin Infect Dis $36: 1221-1228$

147. Ringden O, Meunier F, Tollemar J, Ricci P, Tura S, Kuse E, Viviani MA, Gorin NC, Klastersky J, Fenaux P et al (1991) Efficacy of amphotericin B encapsulated in liposomes (AmBisome) in the treatment of invasive fungal infections in immunocompromised patients. J Antimicrob Chemother 28(Suppl B):73-82

148. Roden MM, Zaoutis TE, Buchanan WL, Knudsen TA, Sarkisova TA, Schaufele RL, Sein M, Sein T, Chiou CC, Chu JH, Kontoyiannis DP, Walsh TJ (2005) Epidemiology and outcome of zygomycosis: a review of 929 reported cases. Clin Infect Dis 41:634-653

149. Rodriguez-Tudela JL, Berenguer J, Guarro J, Kantarcioglu AS, Horre R, de Hoog GS, Cuenca-Estrella M (2009) Epidemiology and outcome of Scedosporium prolificans infection, a review of 162 cases. Med Mycol 47:359-370

150. Ruan SY, Chien JY, Hsueh PR (2009) Invasive trichosporonosis caused by Trichosporon asahii and other unusual Trichosporon species at a medical center in Taiwan. Clin Infect Dis 49:e11-e17

151. Ruhnke M (2006) Epidemiology of Candida albicans infections and role of non-Candida-albicans yeasts. Curr Drug Targets 7:495-504

152. Ruhnke M, Kofla G, Otto K, Schwartz S (2007) CNS aspergillosis: recognition, diagnosis and management. CNS Drugs 21:659-676

153. Ruhnke M, Rickerts V, Cornely OA, Buchheidt D, Glockner A, Heinz W, Hohl R, Horre R, Karthaus M, Kujath P, Willinger B, Presterl E, Rath P, Ritter J, Glasmacher A, Lass-Florl C, Groll AH, German Speaking Mycological Society, Paul-Ehrlich-Society for Chemotherapy (2011) Diagnosis and therapy of Candida infections: joint recommendations of the German Speaking Mycological Society and the Paul-Ehrlich-Society for Chemotherapy. Mycoses 54:279-310

154. Rüping MJ, Heinz WJ, Kindo AJ, Rickerts V, Lass-Flörl C, Beisel C, Herbrecht R, Roth Y, Silling G, Ullmann AJ, Borchert K, Egerer G, Maertens J, Maschmeyer G, Simon A, Wattad M, Fischer G, Vehreschild JJ, Cornely OA (2010) Forty-one recent cases of invasive zygomycosis from a global clinical registry. J Antimicrob Chemother 65:296-302
155. Safdar A, Hanna HA, Boktour M, Kontoyiannis DP, Hachem R, Lichtiger B, Freireich EJ, Raad I (2004) Impact of high-dose granulocyte transfusions in patients with cancer with candidemia: retrospective case-control analysis of 491 episodes of Candida species bloodstream infections. Cancer 101:2859-2865

156. Sansone-Parsons A, Krishna G, Calzetta A, Wexler D, Kantesaria B, Rosenberg MA, Saltzman MA (2006) Effect of a nutritional supplement on posaconazole pharmacokinetics following oral administration to healthy volunteers. Antimicrob Agents Chemother 50:1881-1883

157. Scarcella A, Pasquariello MB, Giugliano B, Vendemmia M, de Lucia A (1998) Liposomal amphotericin B treatment for neonatal fungal infections. Pediatr Infect Dis J 17:146-148

158. Schneider T, Halter J, Heim D, Passweg J, Stern M, Tichelli A, Weisser M, Gerull S (2012) Pre-emptive diagnosis and treatment of fungal infections - evaluation of a single-centre policy. Clin Microbiol Infect 18:189-194

159. Schwartz S, Reisman A, Troke PF (2011) The efficacy of voriconazole in the treatment of 192 fungal central nervous system infections: a retrospective analysis. Infection 39:201-210

160. Schwartz S, Ruhnke M, Ribaud P, Corey L, Driscoll T, Cornely OA, Schuler U, Lutsar I, Troke P, Thiel E (2005) Improved outcome in central nervous system aspergillosis, using voriconazole treatment. Blood 106:2641-2645

161. Schwartz S, Ruhnke M, Ribaud P, Reed E, Troke P, Thiel E (2007) Poor efficacy of amphotericin B-based therapy in CNS aspergillosis. Mycoses 50:196-200

162. Segal BH (2009) Aspergillosis. N Engl J Med 360:1870-1884

163. Segal BH, Herbrecht R, Stevens DA, Ostrosky-Zeichner L, Sobel J, Viscoli C, Walsh TJ, Maertens J, Patterson TF, Perfect JR, Dupont B, Wingard JR, Calandra T, Kauffman CA, Graybill JR, Baden LR, Pappas PG, Bennett JE, Kontoyiannis DP, Cordonnier C, Viviani MA, Bille J, Almyroudis NG, Wheat LJ, Graninger W, Bow EJ, Holland SM, Kullberg BJ, Dismukes WE, De Pauw BE (2008) Defining responses to therapy and study outcomes in clinical trials of invasive fungal diseases: Mycoses Study Group and European Organization for Research and Treatment of Cancer consensus criteria. Clin Infect Dis 47:674-683

164. Seidel MG, Peters C, Wacker A, Northoff H, Moog R, Boehme A, Silling G, Grimminger W, Einsele H (2008) Randomized phase III study of granulocyte transfusions in neutropenic patients. Bone Marrow Transplant 42:679-684

165. Sharkey PK, Graybill JR, Johnson ES, Hausrath SG, Pollard RB, Kolokathis A, Mildvan D, Fan-Havard P, Eng RH, Patterson TF, Pottage JC Jr, Simberkoff MS, Wolf J, Meyer RD, Gupta R, Lee LW, Gordon DS (1996) Amphotericin B lipid complex compared with amphotericin B in the treatment of cryptococcal meningitis in patients with AIDS. Clin Infect Dis 22:315-321

166. Shoham S, Magill SS, Merz WG, Gonzalez C, Seibel N, Buchanan WL, Knudsen TA, Sarkisova TA, Walsh TJ (2010) Primary treatment of zygomycosis with liposomal amphotericin B: analysis of 28 cases. Med Mycol 48:511-517

167. Skiada A, Pagano L, Groll A, Zimmerli S, Dupont B, Lagrou K, Lass-Florl C, Bouza E, Klimko N, Gaustad P, Richardson M, Hamal P, Akova M, Meis JF, Rodriguez-Tudela JL, Roilides E, MitrousiaZiouva A, Petrikkos G (2011) Zygomycosis in Europe: analysis of 230 cases accrued by the registry of the European Confederation of Medical Mycology (ECMM) Working Group on Zygomycosis between 2005 and 2007. Clin Microbiol Infect 17:1859-1867

168. Smith J, Andes D (2008) Therapeutic drug monitoring of antifungals: pharmacokinetic and pharmacodynamic considerations. Ther Drug Monit 30:167-172

169. Suzuki K, Nakase K, Kyo T, Kohara T, Sugawara Y, Shibazaki T, Oka K, Tsukada T, Katayama N (2010) Fatal Trichosporon fungemia in patients with hematologic malignancies. Eur J Haemato 84:441447 
170. Tan BH, Low JG, Chlebicka NL, Kurup A, Cheah FK, Lin RT, Goh YT, Wong GC (2011) Galactomannan-guided preemptive vs. empirical antifungals in the persistently febrile neutropenic patient: a prospective randomized study. Int J Infect Dis IJID Off Publ Intern Soc Infect Dis 15:e350-e356

171. Tedder M, Spratt JA, Anstadt MP, Hegde SS, Tedder SD, Lowe JE (1994) Pulmonary mucormycosis: results of medical and surgical therapy. Ann Thorac Surg 57:1044-1050

172. Thaler M, Pastakia B, Shawker TH, O’Leary T, Pizzo PA (1988) Hepatic candidiasis in cancer patients: the evolving picture of the syndrome. Ann Intern Med 108:88-100

173. Tintelnot K, Just-Nubling G, Horre R, Graf B, Sobottka I, Seibold M, Haas A, Kaben U, De Hoog GS (2009) A review of German Scedosporium prolificans cases from 1993 to 2007. Med Mycol 47:351-358

174. Tortorano AM, Peman J, Bernhardt H, Klingspor L, Kibbler CC, Faure O, Biraghi E, Canton E, Zimmermann K, Seaton S, Grillot R (2004) Epidemiology of candidaemia in Europe: results of 28month European Confederation of Medical Mycology (ECMM) hospital-based surveillance study. Eur J Clin Microbiol Infect Dis 23:317-322

175. Trifilio S, Pennick G, Pi J, Zook J, Golf M, Kaniecki K, Singhal S, Williams S, Winter J, Tallman M, Gordon L, Frankfurt O, Evens A, Mehta J (2007) Monitoring plasma voriconazole levels may be necessary to avoid subtherapeutic levels in hematopoietic stem cell transplant recipients. Cancer 109:1532-1535

176. Troke PF, Hockey HP, Hope WW (2011) Observational study of the clinical efficacy of voriconazole and its relationship to plasma concentrations in patients. Antimicrob Agents Chemother $55: 4782-4788$

177. Ueda K, Nannya Y, Kumano K, Hangaishi A, Takahashi T, Imai Y, Kurokawa M (2009) Monitoring trough concentration of voriconazole is important to ensure successful antifungal therapy and to avoid hepatic damage in patients with hematological disorders. Int J Hematol 89:592-599

178. Ullmann AJ, Akova M, Herbrecht R, Viscoli C, Arendrup MC, Arikan-Akdagli S, Bassetti M, Bille J, Calandra T, Castagnola E, Cornely OA, Donnelly JP, Garbino J, Groll AH, Hope WW, Jensen HE, Kullberg BJ, Lass-Florl C, Lortholary O, Meersseman W, Petrikkos G, Richardson MD, Roilides E, Verweij PE, CuencaEstrella M (2012) ESCMID* guideline for the diagnosis and management of Candida diseases 2012: adults with haematological malignancies and after haematopoietic stem cell transplantation (HCT). Clin Microbiol Infect Off Publ Eur Soc Clin Microbiol Infect Dis 18(Suppl 7):53-67

179. Ullmann AJ, Cornely OA, Burchardt A, Hachem R, Kontoyiannis DP, Topelt K, Courtney R, Wexler D, Krishna G, Martinho M, Corcoran G, Raad I (2006) Pharmacokinetics, safety, and efficacy of posaconazole in patients with persistent febrile neutropenia or refractory invasive fungal infection. Antimicrob Agents Chemother 50:658-666

180. Ullmann AJ, Sanz MA, Tramarin A, Barnes RA, Wu W, Gerlach BA, Krobot KJ, Gerth WC (2006) Prospective study of amphotericin B formulations in immunocompromised patients in 4 European countries. Clin Infect Dis 43:e29-e38

181. van Burik JA, Hare RS, Solomon HF, Corrado ML, Kontoyiannis DP (2006) Posaconazole is effective as salvage therapy in zygomycosis: a retrospective summary of 91 cases. Clin Infect Dis 42:e61-e65

182. Viollier AF, Peterson DE, De Jongh CA, Newman KA, Gray WC, Sutherland JC, Moody MA, Schimpff SC (1986) Aspergillus sinusitis in cancer patients. Cancer 58:366-371

183. Viscoli C, Girmenia C, Marinus A, Collette L, Martino P, Vandercam B, Doyen C, Lebeau B, Spence D, Krcmery V, De Pauw B, Meunier F (1999) Candidemia in cancer patients: a prospective, multicenter surveillance study by the Invasive Fungal Infection Group (IFIG) of the European Organization for
Research and Treatment of Cancer (EORTC). Clin Infect Dis 28:1071-1079

184. Viscoli C, Herbrecht R, Akan H, Baila L, Sonet A, Gallamini A, Giagounidis A, Marchetti O, Martino R, Meert L, Paesmans M, Ameye L, Shivaprakash M, Ullmann AJ, Maertens J (2009) An EORTC phase II study of caspofungin as first-line therapy of invasive aspergillosis in haematological patients. J Antimicrob Chemother 64:1274-1281

185. Wahba H, Truong MT, Lei X, Kontoyiannis DP, Marom EM (2008) Reversed halo sign in invasive pulmonary fungal infections. Clin Infect Dis 46:1733-1737

186. Walsh TJ, Anaissie EJ, Denning DW, Herbrecht R, Kontoyiannis DP, Marr KA, Morrison VA, Segal BH, Steinbach WJ, Stevens DA, van Burik JA, Wingard JR, Patterson TF (2008) Treatment of aspergillosis: clinical practice guidelines of the Infectious Diseases Society of America. Clin Infect Dis 46:327-360

187. Walsh TJ, Finberg RW, Arndt C, Hiemenz J, Schwartz C, Bodensteiner D, Pappas P, Seibel N, Greenberg RN, Dummer S, Schuster M, Holcenberg JS (1999) Liposomal amphotericin B for empirical therapy in patients with persistent fever and neutropenia. National Institute of Allergy and Infectious Diseases Mycoses Study Group. N Engl J Med 340:764-771

188. Walsh TJ, Hiemenz JW, Seibel NL, Perfect JR, Horwith G, Lee L, Silber JL, DiNubile MJ, Reboli A, Bow E, Lister J, Anaissie EJ (1998) Amphotericin B lipid complex for invasive fungal infections: analysis of safety and efficacy in 556 cases. Clin Infect Dis 26:1383-1396

189. Walsh TJ, Raad I, Patterson TF, Chandrasekar P, Donowitz GR, Graybill R, Greene RE, Hachem R, Hadley S, Herbrecht R, Langston A, Louie A, Ribaud P, Segal BH, Stevens DA, van Burik JA, White CS, Corcoran G, Gogate J, Krishna G, Pedicone L, Hardalo C, Perfect JR (2007) Treatment of invasive aspergillosis with posaconazole in patients who are refractory to or intolerant of conventional therapy: an externally controlled trial. Clin Infect Dis 44:2-12

190. Walsh TJ, Whitcomb P, Piscitelli S, Figg WD, Hill S, Chanock SJ, Jarosinski P, Gupta R, Pizzo PA (1997) Safety, tolerance, and pharmacokinetics of amphotericin B lipid complex in children with hepatosplenic candidiasis. Antimicrob Agents Chemother 41:19441948

191. Walsh TJ, Whitcomb PO, Revankar SG, Pizzo PA (1995) Successful treatment of hepatosplenic candidiasis through repeated cycles of chemotherapy and neutropenia. Cancer 76:2357-2362

192. Wang EJ, Lew K, Casciano CN, Clement RP, Johnson WW (2002) Interaction of common azole antifungals with $\mathrm{P}$ glycoprotein. Antimicrob Agents Chemother 46:160-165

193. Wenzel RP, Gennings C (2005) Bloodstream infections due to Candida species in the intensive care unit: identifying especially high-risk patients to determine prevention strategies. Clin Infect Dis 41(Suppl 6):S389-S393

194. Whyte M, Irving H, O'Regan P, Nissen M, Siebert D, Labrom R (2005) Disseminated Scedosporium prolificans infection and survival of a child with acute lymphoblastic leukemia. Pediatr Infect Dis J 24:375-377

195. Wingard JR, Carter SL, Walsh TJ, Kurtzberg J, Small TN, Baden LR, Gersten ID, Mendizabal AM, Leather HL, Confer DL, Maziarz RT, Stadtmauer EA, Bolanos-Meade J, Brown J, Dipersio JF, Boeckh M, Marr KA (2010) Randomized, double-blind trial of fluconazole versus voriconazole for prevention of invasive fungal infection after allogeneic hematopoietic cell transplantation. Blood 116:5111-5118

196. Wingard JR, Kubilis P, Lee L, Yee G, White M, Walshe L, Bowden R, Anaissie E, Hiemenz J, Lister J (1999) Clinical significance of nephrotoxicity in patients treated with amphotericin B for suspected or proven aspergillosis. Clin Infect Dis 29:1402-1407

197. Winkler J, Müller U, Nenoff P, Seyfarth HJ, Vogtmann M, Borte G, Pönisch W, Kahn T, Wirtz H, Schauer J, Hoheisel G (2007) 
Treatment of invasive pulmonary aspergillosis in neutropenic patients by additional bronchoscopic amphotericin B instillation. Respiration 74:663-673

198. Wolf HH, Leithauser M, Maschmeyer G, Salwender H, Klein U, Chaberny I, Weissinger F, Buchheidt D, Ruhnke M, Egerer G,
Cornely O, Fatkenheuer G, Mousset S (2008) Central venous catheter-related infections in hematology and oncology : guidelines of the Infectious Diseases Working Party (AGIHO) of the German Society of Hematology and Oncology (DGHO). Ann Hematol $87: 863-876$ 